\title{
Chapter 2 \\ Mathematical Approaches to Modeling Science from an Algorithmic-Historiography Perspective
}

\author{
Diana Lucio-Arias and Andrea Scharnhorst
}

\subsection{A Narrative of the History of Mathematical Models of Science}

The accumulative nature of knowledge requires systematic ways to comprehend and make sense of what we know. In the case of scientific knowledge, this requirement is enhanced by the importance given to science as a driver of social and economic progress. The persistent interest in a "science of science" or a "social studies of science" is a consequence of the reflexive endeavor to comprehend and assimilate science and the growth of scientific knowledge - perhaps together with policy intentions to design evaluation and stimulus mechanisms.

This interest has led to significant efforts to define and refine ways of modeling, representing, and understanding science in the scientific community - efforts unrestricted to single disciplines or intellectual traditions. Reflection upon knowledge production co-evolves with knowledge production itself. It reaches from early philosophy to the arts, encompassing attempts to order knowledge. One famous example of how to order knowledge is the arbor scientiae of the philosopher Raimudus Lullus (1232-1316) (Dominguez Reboiras et al. 2002).

At the same time, in our modern understanding, the old symbol of the tree also encompasses the idea of evolution. To characterize the evolution of the science system (natural sciences, social sciences, humanities, and arts), its growth and differentiation, mathematical models are one possible scientific method. This book reviews

D. Lucio-Arias $(\square)$

Colombian Observatory of Science and Technology, carrera 15 no 37-59, Bogotá, D.C, Colombia e-mail:dlucio@ocyt.org.co
A. Scharnhorst
Data Archiving and Networked Services, Royal Netherlands Academy of Arts and Sciences, Anna van Saksenlaan 10, 2593 HT Den Haag, The Netherlands
e-mail: andrea.scharnhorst@dans.knaw.nl 
the transfer of models belonging to different branches of an imagined "(sub)tree of mathematics" to scientometrics. Mathematical models in scientometrics are developed to understand better the structure and evolution of the imagined whole tree of knowledge, and so the circle closes. In this chapter, the metaphor of the tree reoccurs once more in the method used to depict the history of mathematical modeling of the sciences. Treelike structures are the core of the historiographic method where, constructed from citations of key papers, they illustrate the evolution of knowledge.

Mathematical models of the sciences do not stand alone in our modern day but stem from formulations made earlier in time. Mathematics has penetrated almost all other scientific disciplines. We not only know mathematical physics and mathematical biology, but also mathematical economics, mathematical sociology, mathematical psychology and mathematical finance. ${ }^{1}$ Although there is no field of "mathematical science studies," the emergence of quantitative studies of science bibliometrics, scientometrics, informetrics - came along naturally together with mathematical approaches. Not surprisingly, methods of statistics are well established in scientometrics (Egghe and Rousseau 1990). However, applications of mathematical models to the dynamics of the science system form relatively singular and isolated events. This observation, together with an increasing need for modeling dynamic processes in science, was not only the trigger for this book, but also the starting point for this chapter.

We can attempt to categorize mathematical models of science according to the phenomena they try to explain and the epistemic approaches they follow. Phenomena include: growth and distribution of expenditures for education and research across countries and fields; number of PhD's in different fields; growth of the number of publications; formation of and competition between scientific fields; citation structures; and different productivity patterns among researchers from different disciplines, taking into account age and gender. Epistemic approaches differ according to their perspective (which can be micro or macro), their basic elements, their units of analysis, and how major dynamic mechanisms of the system under study are identified. Scientific methods are part of the epistemics, so models of science can differ by their use of mathematical technique and mathematical language (see Börner et al. in Chap.1). Concerning mathematical approaches applied to the sciences as an object, we observe a mixture between new mathematical techniques available and newly emerging scientific fields.

In Fig. 2.1, we try to sketch the appearance and diffusion of some mathematical models of science. This sketch is based on the insights of one author who did

\footnotetext{
1 The appearance of separate subject classifications for these subfields or specialization in the Mathematics Subject Classification (MSC) - a system used to categorize items covered by the two reviewing databases, Mathematical Reviews (MR) and Zentralblatt MATH (Zbl) - can indicate the consolidation of mathematical approaches in these fields. According to the MSC2010, mathematical economics encompasses 37 subclasses, mathematical sociology 6, mathematical psychology 5, and mathematical finance 9 (see http://www.ams.org/mathscinet/msc/msc2010. html).
} 
$19^{\text {th }}$ century $20^{\text {th }}$ century

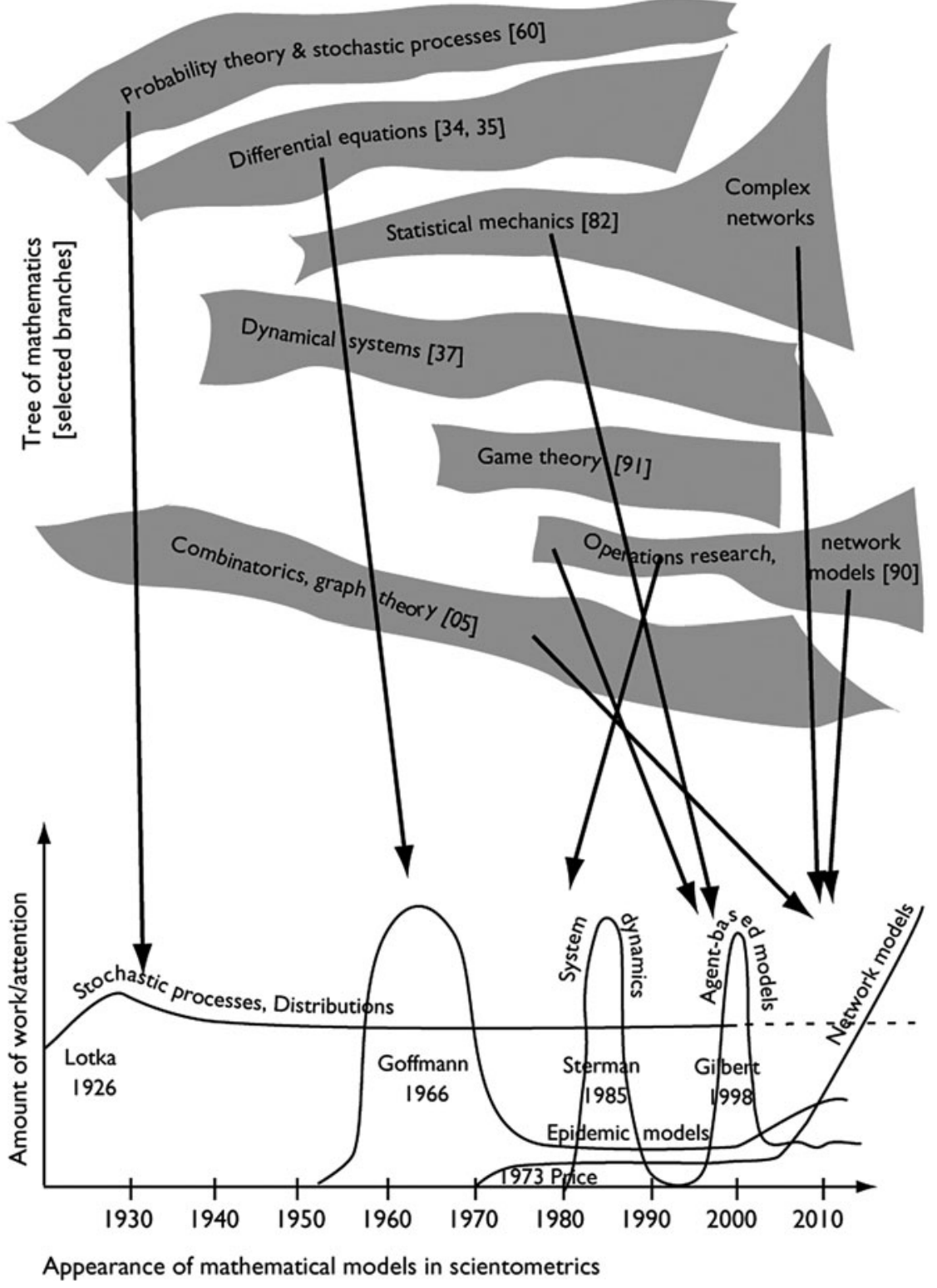

Fig. 2.1 Branches of mathematics and appearance of mathematical models in scientometrics 
her $\mathrm{PhD}$ in this area in 1988 and kept publishing in the field (Scharnhorst 1988; Bruckner et al. 1990). In the upper part of Fig. 2.1, branches of mathematics are selected (labeled according to the Mathematics Subject Classification) according to their relevance for models of science. Of course, inside mathematics, these branches overlap and form a fabric (Boyack and Klavans 2009), or turbulent, reactingdiffusing fluids, rather than a static tree with separable branches. The lower part of Fig. 2.1 depicts growth curves of certain models of science. However, there is no linear causality between a certain progress in mathematics and its possible application to the science system, even if we indicate relations by arrows as in Fig. 2.1. Few models enter the field of scientometrics via biology, psychology, economy, or physics. Last but not least, it all depends if researchers are intrigued enough by the problem to model mathematically the sciences as a cognitive and social system.

For the time being, we would like to stick to such a narrative that combines epistemic streams running across different disciplines with the first occurrence of certain types of models applied to science as a system. In the main part of the paper, we search for empirical evidence supporting or contradicting this historical narrative.

We state that in parallel with the emergence and spreading of "approaches and techniques" (for example, stochastic distributions at the end of the nineteenth century; the emergence of system science and operations research; the paradigmatic change in physics towards irreversible, dissipative and complex processes; and the rise of rule-base agent modeling, to name only a few), researchers - most of the time also pioneers in developing these methods - were curious also to apply them to an environment in which they felt at home: the academic system.

For instance, Lotka described the skewed distribution of the productivity of scientists (Lotka 1926) as part of his more general approach to apply methods of (statistical) physics to evolution in nature as well as society (Lotka 1911). Sterman's system-dynamics model of Kuhn's scientific revolution (Sterman 1985) is embedded in his overall work on complex social systems, part of the emergence of system dynamics as a specific mathematical systems theory (Sterman 1992), and just another exemplification of feedback loops and complex correlations between dynamic micromechanisms. Goffman modeled the diffusion of ideas similarly to the spreading of diseases, and other researchers (Nowakowska, Kochen, Yablonsky, Bruckner et al.) compared the emergence of scientific fields to the evolution of biological species. They all made use of differential equations and master equations at the moment non-linear differential equations became very popular ways to describe the dynamics of complex systems (Nicolis and Prigogine 1977). Gilbert's agent-based model of science (1997) marks the entry and spread of rulebased modeling into mathematical and computational sociology (Epstein and Axtell 1996), for which Gilbert also did pioneering work (Gilbert and Troitzsch 2005). Furthermore, the interest of Gilbert was also obviously triggered by his earlier work on the history and sociology of science (Gilbert and Mulkay 1984).

But not in all cases do we find a strict temporal correlation between the establishment of the mathematical method and its testing out for the science system 
as one specific social system. In the case of game theory, developed in the 1930s and 1940s (see von Neumann and Morgenstern 1944), only now is the method tested upon science itself (see Hanauske in Chap. 5).

Moreover, there are differences in the way the scientific community has embraced these pioneering approaches. Lotka's law is known today as a classic law in scientometrics. Stochastic processes, which can explain also Lotka's law, have been present almost the whole time (e.g., Glänzel and Schubert 1995; Van Raan 2006; Egghe 2005). However, Lotka's general framework of a physics of evolution applicable to processes in nature and society did not travel. Even more, his famous systems of non-linear differential equations (Lotka-Volterra equations), applied extensively in mathematical biology (Lotka 1925), did not travel, at least not through Lotka's own initiation. Although Goffman's epidemic model belongs to the same type of models, the link to Lotka-Volterra equations has been made explicit only in the 1980s. After seeing a first rush in the 1960s, 1970s and 1980s, epidemic models themselves only reappeared in the context of epidemic processes on networks, together with the emergence of a cross-disciplinary network science (2005), from 2000 onwards. In the same context of the revival of networks, other early network models like Price's gain a second period of attention. In contrast, applications of agent-based models and system-dynamics models remain rare occurrences. Yet, agent-based models - outside of scientometrics and independent from it - have been embraced by computational philosophy, which uses concepts and mathematical approaches for epistemic spaces and dynamics quite similar to those used in scientometrics ((Weisberg and Muldoon 2009) see Payette in Chap. 4). All in all, the impression emerges that mathematical models applied to science come in waves, remain relatively independent from each other, and form more an ephemeral than a persistent thread in scientometrics (Fig. 2.1).

This is quite interesting. Why, unlike other sciences, does the modeling of science dynamics appear as a process of eternal beginning, and why does it still lack a coherent theoretical framework? Can we find facts for such an impression now turned into a hypothesis? Can bibliometrics confirm that we indeed are faced today with modeling approaches to science that are scattered, while older approaches might have been obliterated or forgotten with time? Can historiographic analysis also reveal some of the causes for such a situation?

The purpose of this chapter is to counter an individual account of science history with a bibliometric study. We present a historiography of mathematical models and approaches to science. This will give the opportunity to reveal the cognitive history of the models. What might seem unrelated today might share a cognitive or disciplinary memory or might stem from significant older papers that had citation relations between them. We follow this section with a description of the method of algorithmic historiography to reveal scientific developments. This method is later used to (a) delineate the cognitive historiography of today's mathematical approaches to science and (b) illustrate approaches to science constituting a lasting thread that may have been forgotten or obliterated by new models. 


\subsection{The Use of Bibliometrics in Science History - Algorithmic Historiography}

Publishing as a means of communicating, corroborating, or refuting scientific findings is a crucial operation for the development of scientific knowledge (LucioArias and Leydesdorff 2009). For this reason, citation practices have also become established in this discursive construction of scientific knowledge (Wouters 1999). Early in the invention of citation indexing, which was primarily aimed at advancing information retrieval, Garfield proposed to use these databases to reconstruct the history of scientific ideas (Garfield et al. 1964). The bibliographic information contained in a collection of published articles and their references makes historical reconstruction through citations a collective and social enterprise (ibid.). However, one has to keep in mind that looking at citations represents a specific empirical method. Both bibliometrics and scientometrics have known a long and continuing debate over the meaning of citations in knowledge production, dissemination, and reconstruction (De Bellis 2009). Recently, it has been observed that "it remains a question what actually bibliometrics can add to science history based on text analysis and eye witness accounts" (Scharnhorst and Garfield 2010). The method of algorithmic historiography as applied in the following is therefore used as one possible empirical method to test some of the hypotheses presented in the previous section, and the results make explicit the limitations of this method.

The notion of algorithmic historiography is supported by the introduction of HistCite $^{\mathrm{TM}}$ as a bibliometric tool that aids the process of uncovering transmissions of knowledge that lead to scientific breakthroughs (Pudovkin and Garfield 2002). It relies on citation data to describe historically scientific fields, specialties, and breakthroughs (Garfield 1979). The software creates a mini-citation matrix for any set of documents retrieved from the ISI Web of Science, facilitating historical reconstructions based on a literary simplification of science (Garfield et al. 2003b,a, 2005). Depending on the seed nodes selected to start the citation, mining the method can be applied to a scientific field or a journal, the oeuvre of a scholar, or an individual paper (Scharnhorst and Garfield 2010).

The method of utilizing the textual footprint of scientific discoveries and breakthroughs to reconstruct their history has been employed in scientometrics. Citations might be considered as the memory carriers of the system, and their use as nodes in network-like historiographs can be further enhanced by using algorithms from network and information theory (Lucio-Arias and Leydesdorff 2008). Even though this approach is used to a lesser extent by philosophers and historians of science, the algorithmic approach to historical reconstruction enables us to include more variety in the perspective than a reconstruction based on dispersed narratives (Kranakis and Leydesdorff 1989). This approach, labeled scientometric historiography, relies on citation networks to build descriptive reconstructions of history, assuming that these networks reflect a transmission or flow of ideas between papers.

Possible biases caused by the use of citations for empirical reconstructions might include the overestimation of contributions from elite scientists (MacRoberts 
and MacRoberts 1987, 1989), negative or critical citations, or the perfunctory acknowledgement of earlier work. Nevertheless, different studies have agreed that around $70 \%$ of the references used in a scientific paper correspond to criteria of scientific relevance (Vinkler 1996; Krampen et al. 2007). In other words, $70 \%$ of citations respond to the normative theory of citing (Cronin 1984), which justifies the value of citation analysis for historical reconstruction of scientific fields. We use the main-path algorithm from social network analysis to identify those central documents in the citation networks. Specifically, we use the Search Path Link Count available in Pajek which accounts for the number of all possible search paths through the network emanating from an origin (Hummon and Doreian 1989; Batagelj 2003). These main paths have been acknowledged to identify documents that build on previous work, while acting as authorities for later works (Yin et al. 2006). These documents can be expected to be associated with thematic or methodological transitions in the development of a topic (Carley et al. 1993) and are significant for writing the history of science (Hummon and Doreian 1989).

In the following sections, we use two different approaches to chronological networks of citations. Citations allow us to study the diffusion of ideas among documents. But citations can also be understood in the process of codifying scientific knowledge. They link older texts to today's scientific knowledge while providing information about the cognitive position of scientific knowledge claims, which through citations and references get contextualized in scientific repertoires and trajectories. Citations give disciplinary context to publications. We will take both of these perspectives into account in the following sections. In the first part of the results section, we will present the bibliographic history of mathematical models used today to study science. We expect to encounter well-known pioneers like the models mentioned throughout the book, but we will also encounter lesser-known models that may have been obliterated or forgotten over time. We will show how different threads are codified in relation to different "classical" or seminal approaches to mathematical models of science. The second reading given in the results section corresponds to the trajectories constructed from the diffusion of seminal approaches to science modeling. We reconstruct the diffusion of the ideas introduced by Alfred J. Lotka, Derek de Solla Price, and William Goffman based on citation analysis.

\subsection{Data Selection and Analysis Design}

In this chapter, we use bibliometrics to study and follow the implementation of mathematical models for science. The purpose will be to uncover different characteristics of the process of codifying mathematical models that have been published in the last 5 years in selected journals of Library and Information Science. In this section, we look at the knowledge base of this set of papers to determine their cohesiveness. The method of using mathematics to model the structure and behavior of science presents scattered trajectories that could respond to the lack of a unifying theory or intellectual base. In a later section, some of the models that appear in chapters of this book will be presented from the perspective of their 
Table 2.1 Statistics of the search: present to past

\begin{tabular}{llcl}
\hline Journal & Documents & Inside citations & Total citations \\
\hline JASIST & 50 & 39 & 416 \\
Scientometrics & 47 & 44 & 271 \\
IP\&M & 20 & 5 & 63 \\
J. Informetrics & 20 & 13 & 53 \\
Total documents & & 137 & \\
\hline
\end{tabular}

Source: ISI Web of Science, query May 25, 2010, HistCite ${ }^{\mathrm{TM}}$.

diffusion trajectories. This will emphasize possible recombinations, cognitive links, or disciplinary shifts that affect the appropriation of the models in the scientific community. In this specific section, the diffusion trajectories are detailed in relation to the characteristics of the models presented in the introductory chapter of this book.

All our analyses are based on retrievals from the Thomson Reuters Web of Science, which can easily be read by the HistCite ${ }^{\mathrm{TM}}$ software.

For the cognitive history of contemporary papers using (or referring to) mathematical models of science (Present to past analysis - Sect. 2.4.1), we selected four major journals in ISI's subject category of Library and Information Science. The selection of the journals was determined by their popularity inside the community of the information sciences. For retrieving documents using mathematical approaches to science, we first used a topical search in the ISI Web of Science $^{2}$ that retrieved 2,876 documents. However, we encountered the problem that the majority of them were not in line with the purpose of our study. For this reason, we decided to download all documents published in Scientometrics, Journal of the American Society for Information Science and Technology, Journal of Informetrics, and Information Processing and Management in the period considered. We made a manual selection based on the titles, abstracts, and full text (when necessary) of those documents that used mathematical approaches (ideally models) to explain science. The drawback of this last approach is that there are various mathematical models in existence. There is also an ambiguity in the use of the word "model" and even "mathematical model." Many of the documents selected claimed to be modeling approaches but failed to have all the specifications necessary to be considered as such. Table 2.1 gives an overview of the number of retrieved documents per journal, as well as the citations inside the retrieved set of documents (inside citations) and in the whole web of science (total citations). ${ }^{3}$ Table 2.1 also presents a summary of the volume of papers selected according to the sample of journals taken. The whole set of 137 documents selected as referring to mathematical models of science for 2005-2010 is available at the end of this chapter in Appendix 1.

The software HistCite ${ }^{\mathrm{TM}}$ was used to build the inner-citation matrix of these documents to illustrate their cognitive relatedness. Because they might be related in a citation window larger than the years considered, the set was expanded to include the most highly cited documents inside the set.

\footnotetext{
${ }^{2}$ Query used: ts $=$ (model* same (science or scientific or knowledge)).

${ }^{3}$ For comparable analysis, the whole data set can be requested from the authors.
} 
For the second part of the analysis, the diffusion trajectories of three different models were chosen according to their relevance and impact in scientometric studies. We chose Lotka's law, Goffman's epidemic model, and Price's network model. The three models differ in character. Lotka's law is a statistical description (a descriptive model) of certain structures in science. Goffman's model departs from assumptions of basic mechanisms of science on a micro level to reveal structures on a macro level due to the dynamics imposed. It can be used for description as well as for prediction. Price's network model is a conceptual one that reflects upon possible disciplinary meanings that emerge from the network structures formed by citation relations between papers. It is empirically verified and exemplifies phenomena such as obliteration, the relation between references and citations, and the emergence of research fronts. However, there is only a small step between descriptive models and predictive models. Distributions, as in the case of Lotka's law, have been explained from stochastic processes. Price has himself later proposed mathematical models for the micromechanisms behind some of the features he explores in his "Network" paper (Price 1976). The popularity of Lotka's law as one of the few basic laws of science and the fact that it operates at the border between descriptive and predictive models were the reasons we included Lotka's law in our selection. In the case of Price's network model, we chose an example of a comprehensive and classical description of a basic pattern in scientific communication that has inspired

Table 2.2 Seed documents

\begin{tabular}{|c|c|c|c|}
\hline Model & Seed documents & $\begin{array}{l}\text { \# cites } \\
\text { (papers } \\
\text { considered) }\end{array}$ & $\begin{array}{l}\text { Citation } \\
\text { window (in } \\
\text { years) }\end{array}$ \\
\hline $\begin{array}{l}\text { Lotka-Volterra } \\
\text { model }\end{array}$ & $\begin{array}{l}\text { Lotka, A.J. (1926). The frequency } \\
\text { distribution of scientific } \\
\text { productivity, J. Wash. Acad. } \\
\text { Sci., 16: } 317\end{array}$ & 612 & 1939-2010 \\
\hline $\begin{array}{l}\text { Price network } \\
\text { model }\end{array}$ & $\begin{array}{l}\text { Price, D.J.D. (1965). Networks of } \\
\text { scientific papers. The pattern of } \\
\text { bibliographic references } \\
\text { indicates the nature of the } \\
\text { scientific front, Science, } 149 \\
\text { (3683): } 510-515\end{array}$ & 497 & 1978-2010 \\
\hline $\begin{array}{l}\text { Goffman epidemic } \\
\text { model }\end{array}$ & $\begin{array}{l}\text { Goffman, W. (1966). Mathematical } \\
\text { Approach to Spread of } \\
\text { Scientific Ideas - History of } \\
\text { Mast Cell Research, Nature, } \\
212(5061): 449 \\
\text { Goffman, W., \& Newill, V.A. } \\
\text { (1964). Generalization of } \\
\text { Epidemic Theory: An } \\
\text { Application to the } \\
\text { Transmission of Ideas, Nature } \\
\text { 204: } 225 .\end{array}$ & 73 & 1975-2010 \\
\hline
\end{tabular}

Source: ISI Web of Science, query May 25, 2010. 
many other reflections, some of them mathematical. We explain each model at the beginning of the corresponding results section.

Table 2.2 depicts the documents that were used as seed documents for these models. It shows the amount of times the chosen seed documents were cited and the publication years of those citing documents. All documents citing these seeding documents were downloaded and analyzed according to their modeling characteristics.

The downloaded citing documents were content analyzed to identify the purpose of the paper (if it was a mathematical approach, an application or refutation of informetric laws with empirical evidence, an evaluation or assessment exercise in a specific context, etc.).

\subsection{Results}

\subsubsection{The Current Presence of Mathematical Modeling in Library and Information Science - Following Traces from the Present to the Past}

To analyze the intellectual base of the papers that are currently applying mathematical models to study science, we started from our sample database (Table 2.1), which consists of 137 documents published in leading journals in ISI's subject category of Library and Information Science from 2005 to 2010. These papers were taken as seeds for a HistCite ${ }^{\mathrm{TM}}$ analysis with the purpose of tracing the citation relations inside the set. The resulting historiograph (Fig. 2.2) depicts documents as nodes, where the size of the node represents the amount of citations it gets inside the considered set (outside citations are not taken into account). The arrow represents a citation relation. We start from the current papers, dig into their bibliographies and look for cross-connections. We also try to see how persistent models are, and which mathematical models we encounter.

Figure 2.2 shows the citation diagram for the current mathematical approaches to science. The number of the nodes corresponds to the numbers of the 137 documents in table 2.6 in the first appendix. Most of the nodes are related to stochastic processes in informetric data.

Already, one sees that the documents dealing with mathematical models belong to different, isolated threads. We present a zoom of four of them in the subsequent figures and label the nodes that are cited inside the set with their bibliographic references.

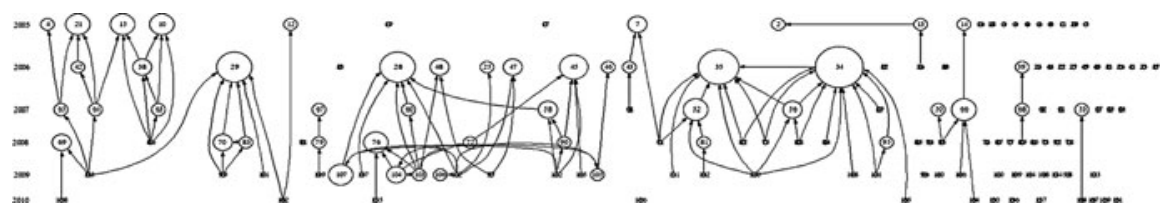

Fig. 2.2 HistCite $^{\mathrm{TM}}$ output of papers using mathematical approaches to understand the science system - overview 


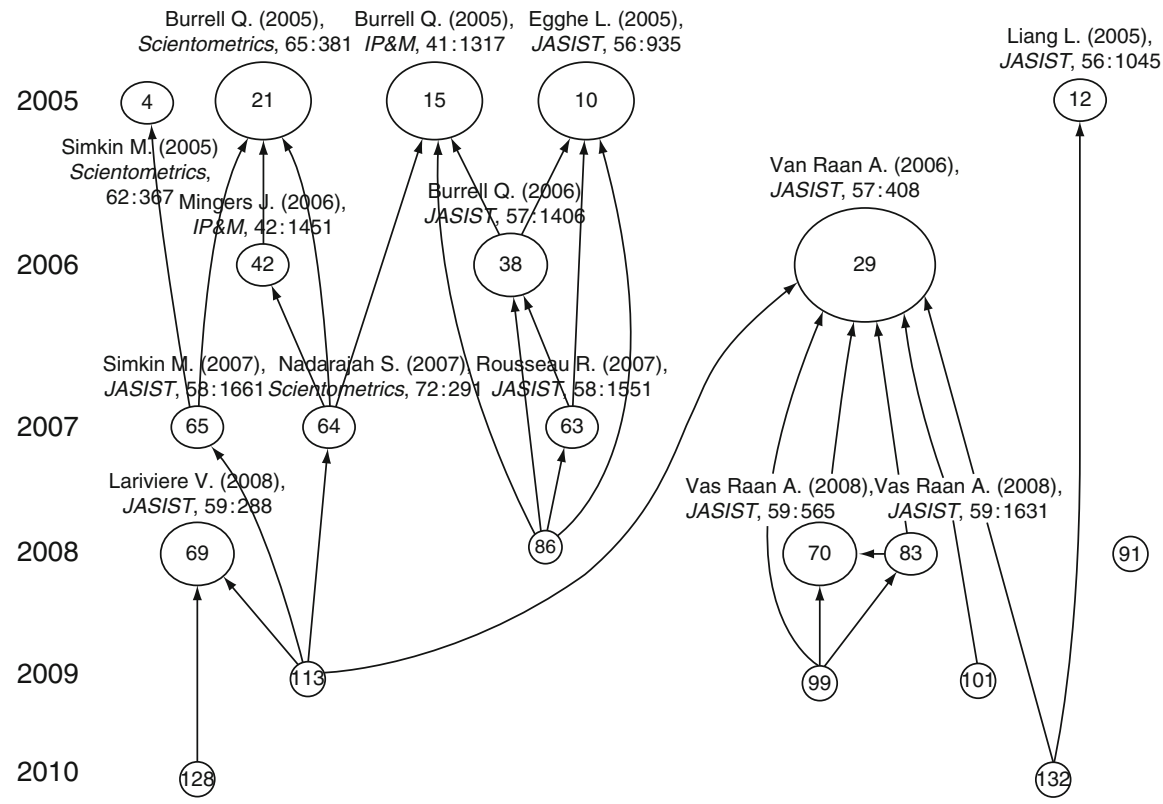

Fig. 2.3 First thread in the current HistCite ${ }^{\mathrm{TM}}$ graph of mathematical model papers

In the first group, from left, we find a paper by Van Raan (29) about statistical properties of indicators. Some of the papers in our set emphasize modeling and explaining through mathematical formulations citing behavior and growth (e.g., Nodes 4, 10, 15, 21, 38, 42, 63, 64, 65, 83 and 108). The complete list of documents of this first group can be found in table 2.8.

As we move in Fig.2.2 from left to right (or from Figs. 2.3 to 2.6), more sophistication is added to the approaches, going from explanations and refinements based on the Hirsch index, to model impact and relevance of authors, to research group behavior (e.g., Nodes 29, 70, 83). However, most of the papers explain the static structure of science. In the last few years, the efforts that have been undertaken to explain growth in the system of science seem unrelated to the rest of the papers (e.g., Nodes 2, 13, 70, 76, 96).

In the second group, we find papers about network algorithms and approaches to mapping science - particularly, old and new approaches (Small 48, Börner 46, Klavans 47) and Chen's citespace software (28). This thread interestingly binds mapping and network approaches with predictive models on epidemics of idea spreading (Bettencourt 76) and the peer review process (Bornmann 67). (A list of all papers is given in table 2.9 of Appendix 3.) All the nodes for the year 2009 correspond to the "Science of Science" special issue of the Journal of Informetrics.

A third group entails a paper about statistical features of the Hirsh-index, the newest challenge to bibliometric rankings (e.g., Nodes 34, 35, 56). Documents in the third thread are illustrated in Figure 2.5 and detailed in table 2.10 of appendix 3. 


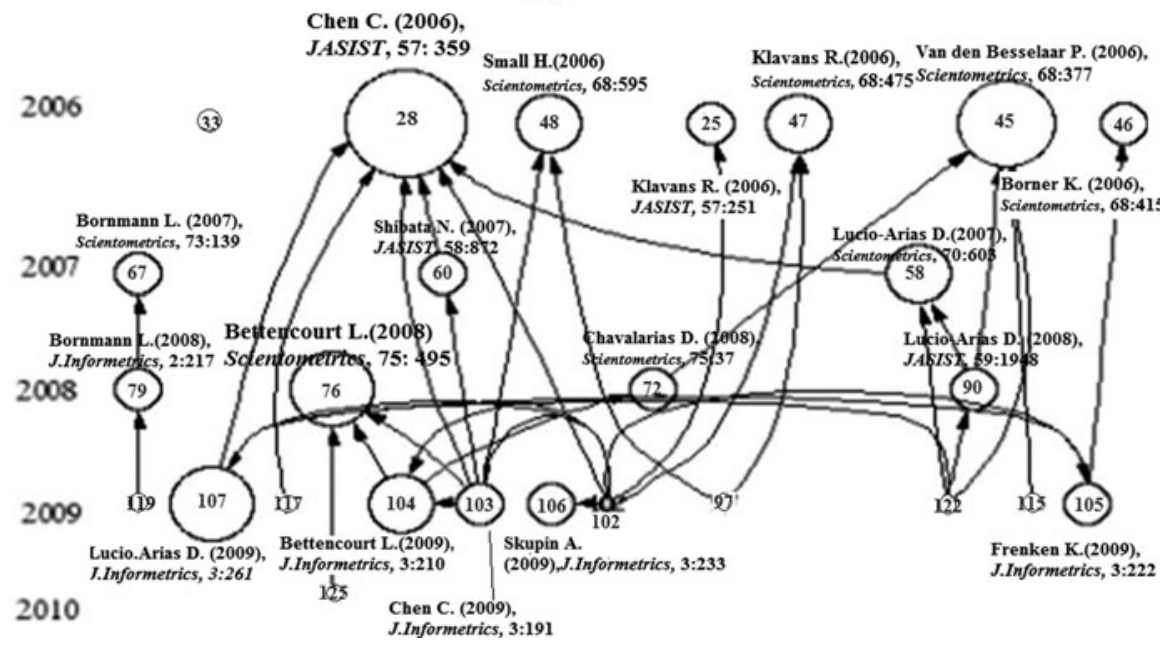

Fig. 2.4 Second thread in the current HistCite ${ }^{\mathrm{TM}}$ graph of mathematical model papers

Egghe L. (2005) 2005 JASIST, 56:669

2007

2008

2009

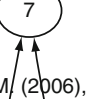
\& $\$$, 42,1513

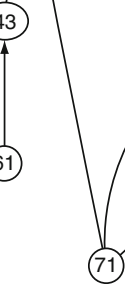

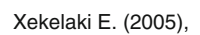

Burrell Q. (2005), Scientometrics, 64:247

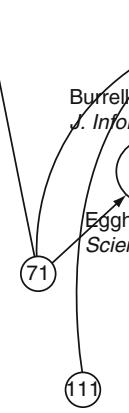

(126)

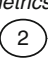

\section{3}

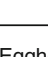

Egghe L, 2006,

Scientometrics, 69:121
Glanzel W. (2006)

Scientometrics, 67:315

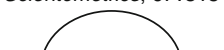

35
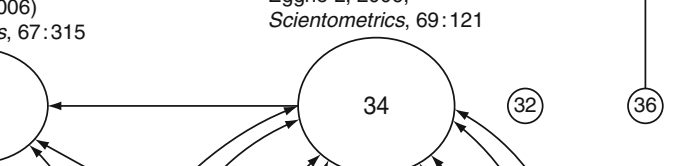
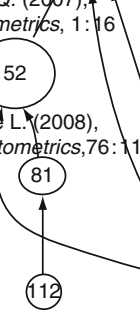

82

(12)

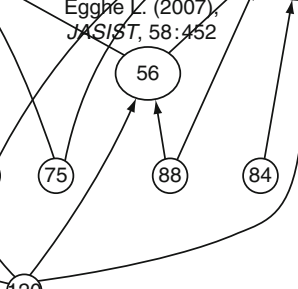

Eggne) (2007)
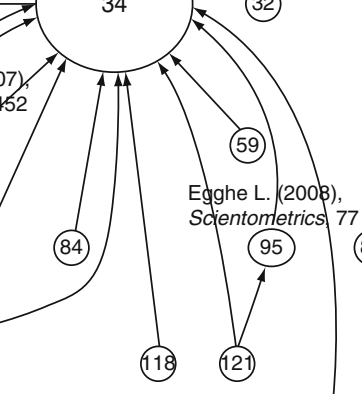

(85)

2010

Fig. 2.5 Third thread in the current HistCite ${ }^{\mathrm{TM}}$ graph of mathematical model papers

The documents in the fourth thread (Fig 2.6) are detailed in table 2.11 of the same appendix.

Comparing our analysis of the different threads with Fig. 2.7, one can see that although many of the documents treat similar issues (especially stochastic behavior), 


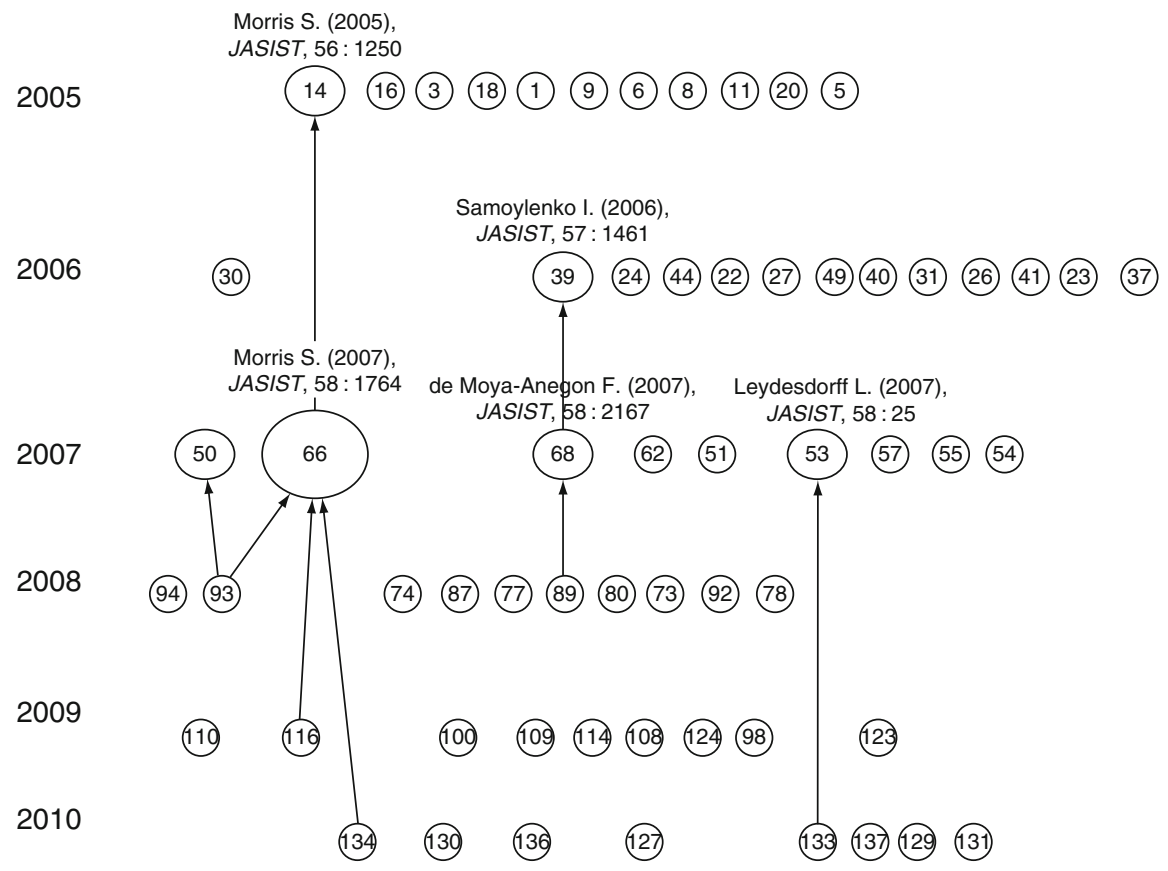

Fig. 2.6 Fourth thread in the current HistCite ${ }^{\mathrm{TM}}$ graph of mathematical model papers

there is no clear relation between them. For instance, Node 76 (in Fig. 2.4) represents the paper by Bettencourt, Kaiser, Kaur, Castillo-Chávez \& Wojick from 2008 that reuses the model of epidemic approaches for the transmission of ideas; as can be seen in the historiograph, this node does not have any citation relation with the other papers in the set.

Strikingly, the bibliometric analysis seems indeed to confirm the historic narrative. Mathematical models of the sciences are divided into different branches and exist largely in isolation, as can be seen by the occurrence of many single points at the right side of both Figs. 2.2 and 2.7.

The isolation of the sets might respond to functional differentiation that results from the growth in scientific publications, and that allows scientists to reduce the levels of complexity in different disciplines (Lucio-Arias and Leydesdorff 2009). This means that the apparent isolation between sets might be reduced when looking at the bibliographic antecedents of these models. In Fig. 2.7, the most cited documents outside the set of the 137 documents selected for treating science with mathematical models and approaches were incorporated to construct a new historiograph.

From Fig. 2.7, it can be deduced that, even if different papers are not closely related to other contemporary approaches, they seem to have a common cognitive historiography, and there is a consensus on classical or seminal approaches to current modeling exercises to understand the sciences. In Fig. 2.7, the main path 


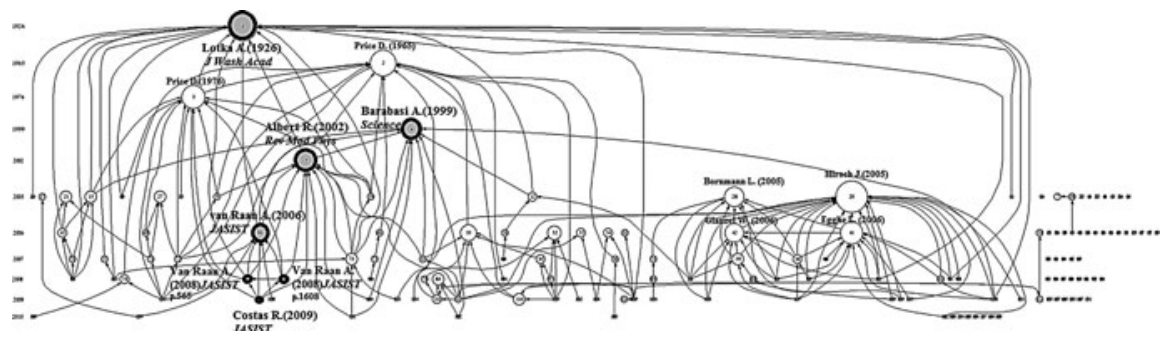

Fig. 2.7 HistCite $^{\mathrm{TM}}$ output of papers using mathematical approaches to understand the science system, enhanced with their cognitive history

of the set is highlighted in gray. Lotka's seminal paper, which originated Lotka's law on scientific productivity based on the skewed distributions of authors, is the starting point; due to the interdisciplinary nature of the paper, the next two documents highlighted in the main path - Barabasi and Albert (1999) and Albert and Barabasi (2002) - are also foreign to the field of Library and Information Science and, more specifically, to scientometrics. These papers deal with networks as random graphs from a physics perspective; the next nodes in the main path (36, 77 and 90 - Van Raan (2006, 2008a, 2008b) reflect the discourse about the importance of impact upon research groups and individuals. Interestingly, from this wider perspective, statistical physics and complex networks, as well as rankings and indicators, seem to be interwoven into one network of exchange of ideas.

The scattered impression depicted in Figs. 2.2-2.6 reflects the sparse relatedness of mathematical approaches inside of Library and Information Science. It can also be interpreted as a lack of consolidation around mathematical methods and as competition between different threads of mathematical modeling that are related in principle but divided in practice. Figure 2.7 shows that when overlooking larger parts of the scientific landscape, these isolated branches or points are interconnected. One could say that the generic and universal character of mathematical approaches that can act as bridging and transporting structures of knowledge diffusion is more visible in Fig. 2.7. In any case, the comparison of Figs. 2.2 and 2.7 shows the relevance of the selection of the seed nodes. It also shows the restriction of a too inner-field perspective. The position of mathematical modeling in scientometrics cannot be fully understood from the field's perspective only. We need to look at the tension of evolution inside of one field and among different fields. "Neighboring fields"4 of Library and Information Sciences might be seen as a relative constant and as a neglected environment if it concerns threads inside of LIS that are mature. For a rather marginal topic such as dynamic models of science, they gain importance as a source of ideas travelling into LIS.

For Fig. 2.7, the set of 137 documents dealing with mathematical approximations to science from the perspective of Library and Information Science was studied;

\footnotetext{
${ }^{4}$ Independently how we define neighborhood here.
} 
included in the set were the most highly cited documents (144 documents in total detailed in table 2.7). While the recent documents could be considered the research front of the field, the highly cited ones can be considered the intellectual base (Chen 2006). The main path has been acknowledged in scientometric studies to represent the backbone of a journal or a field (Hummon and Doreian 1989; Carley et al. 1993). Nevertheless, the main path depicted in Fig. 2.7, although highlighting important documents in the topic of mathematical models of science, cannot be taken as the main achievements of the field. The reason is that the set does not represent a cohesive specialty or discipline.

We used bibliographic coupling of authors to measure cognitive cohesiveness in terms of similarities between reference lists in the set of papers. This coupling technique uses author names as variables and the references as cases. To correct for productive authors with many papers, cosine normalization is applied. Figure 2.8 illustrates the results for 187 authors publishing mathematical models of science.

While Figs. 2.2-2.7 illustrate the citation network as a chronological network of citation where documents are organized according to their publishing year and their bibliographic antecedents and descendents, the coupling in Fig. 2.8 corresponds to authors based on the similarities of the referenced works in their papers. It supports the suggestion of Fig. 2.8 of a common cognitive history in these approaches to modeling science.

\subsubsection{The History of Mathematical Modeling of the Science System - Following Traces from the Past to the Present}

\subsubsection{Lotka, Goffman, Price: Overall Growth and Diffusion of Reception}

In this section, we present the diffusion trajectories of three specific models: Lotka's law (as discussed in Chap. 3 of this book), Goffman's epidemic model (see also Chap. 3), and the network model introduced by Derek de Solla Price (addressed also in Chap. 7 of this book, Fortunato et al.). Even though the three models remain very relevant in the information sciences, their impact measured in terms of citations varies (see Fig. 2.9 and 2.10). Lotka and Price are still widely cited, while Goffman has received less attention throughout the years. The total number of citations is 612 for Lotka's paper of 1926, 73 citations for Goffman's two papers, and 497 for Price's paper from 1965. It should be noted that even though the four seminal papers chosen for the analysis describe models applied specifically to the study and understanding of the science system, none of them were published in Library and Information Science journals. Additionally, only Price is considered a pioneer in the scientific community. His influence results from a series of documents and papers that keep him visible in the scientometric community. Both Derek de Solla Price and Alfred J. Lotka have around 50 papers in the ISI Web of Science, while William Goffman has little more than 25 . 


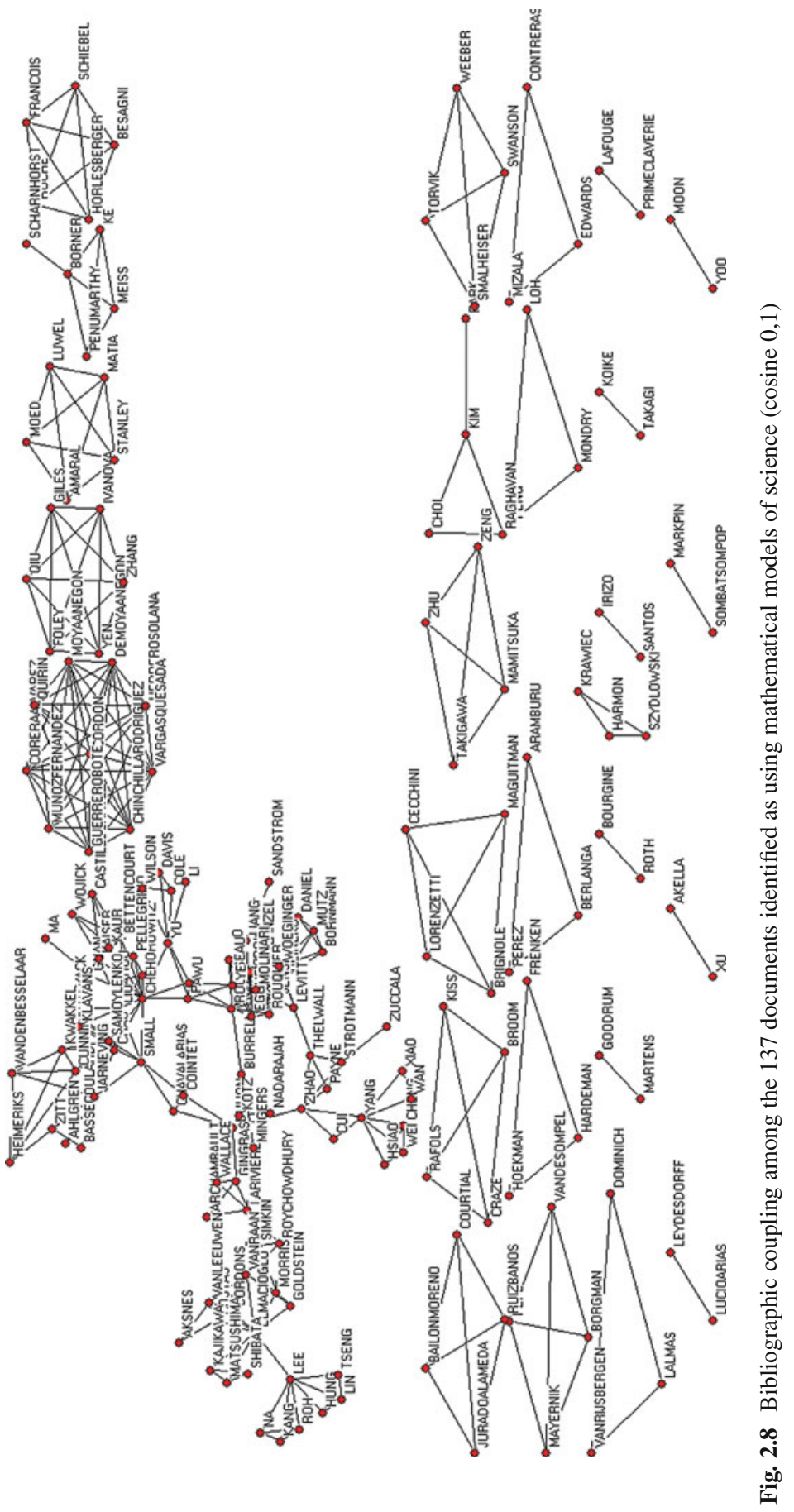




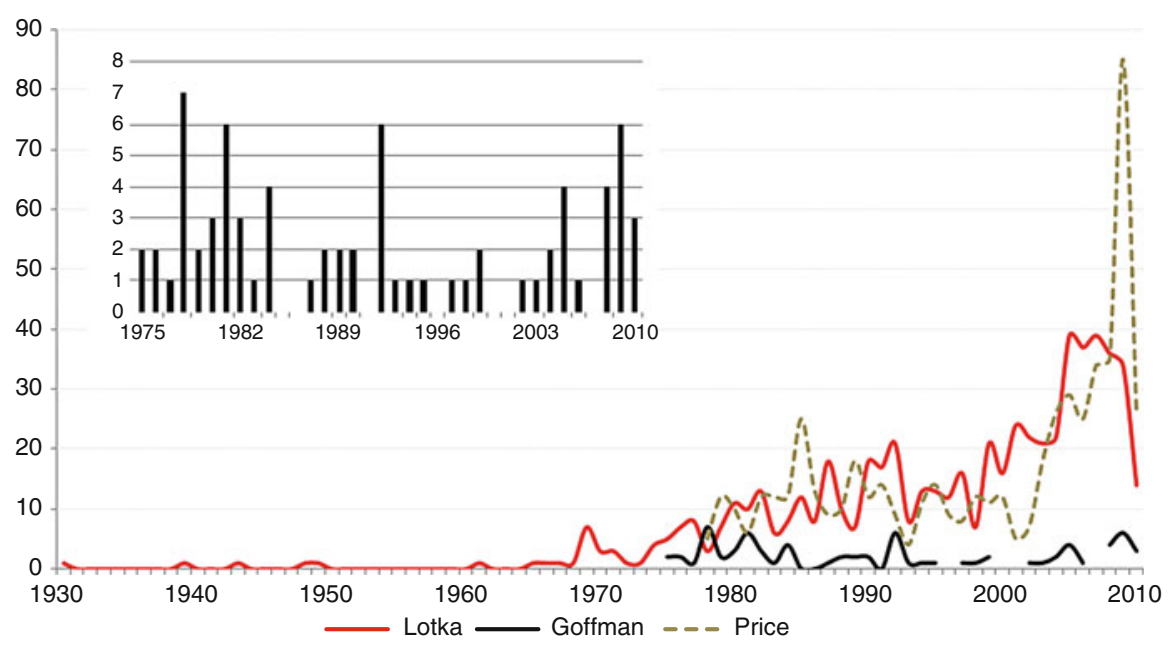

Fig. 2.9 Growth of papers citing the three historical models - Lotka's law, Goffman's model, and Price's model. The yearly citations of Goffman's two papers are shown within the inlay

Figure 2.9 shows the annual number of citations for three cases. In the case of Lotka, we see that his model is still influential eight decades after its publication, although it took some years for it to become popular in the scientific community. The reception of Price and Lotka (at least of their papers of 1926 and 1965) seems to be similar. Although there is also an underlying growth of the Web of Science, the reception of both papers grows together with the consolidation of scientometrics as a field (Lucio-Arias and Leydesdorff 2009).

For the case of Goffman, there are few documents citing the two selected papers. Therefore, we have displayed the annual citation numbers in an additional figure as an inlay in Fig. 2.9. From this bar chart, we can see that the annual numbers are small, the papers disappear from the radar now and then, and there is a kind of revival of popularity beginning around 2000. With its more robust growth of perception, the Price model also seems to gain popularity after 2000. Actually, both models - Goffman's as well as Price's - have also been discussed together with the emergence of network science and the application of network science to the science system (Börner et al. 2007).

We also display the HistCite ${ }^{\mathrm{TM}}$ graphs for all three cases (four papers) for a visual impression. As can be seen from Fig. 2.10, they are quite different in nature. While the graphs are very dense for the case of Lotka's and Price's models, in the case of Goffman's model there are fewer nodes and a more sparsely connected network. We will look into the diffusion pattern in all three cases separately in more detail. 

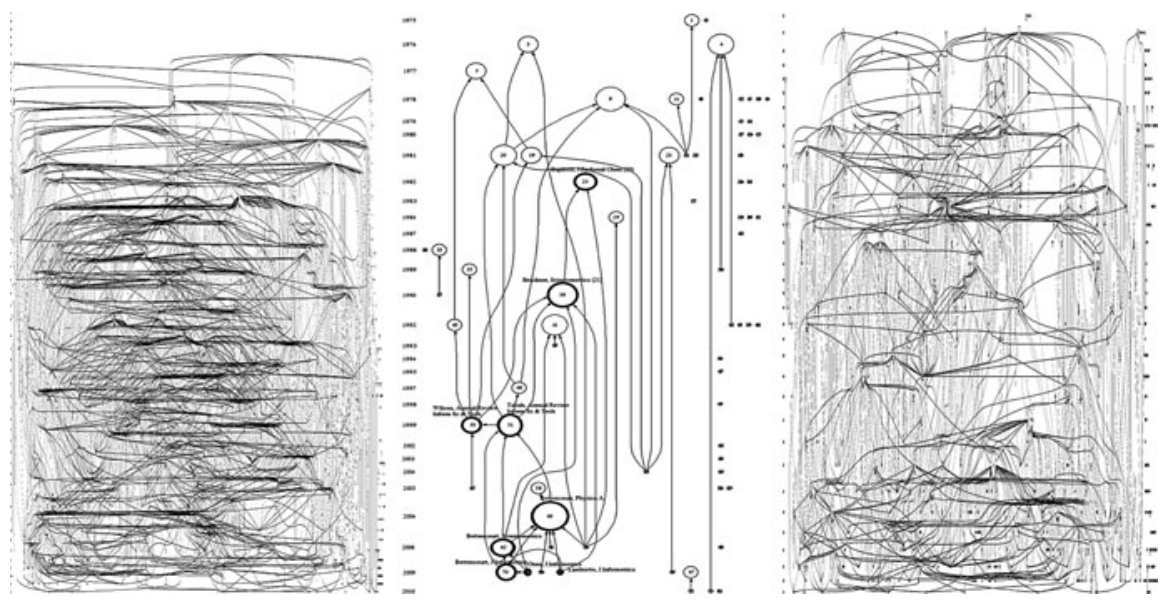

Fig. 2.10 Historiographs for Lotka (left), Goffman (middle), and Price (right) - overview

\subsubsection{Physics of Evolution: From Biological Species to Productive Actors - A.J. Lotka}

Lotka's law reflects a regularity concerning the productivity of scholars (measured by the number of publications). Lotka found that a majority of authors (consisting of a given set of authors) only produce one publication in a given period of time and only very few authors publish larger amounts of articles. If the number of authors with $n$ publications is plotted against the aggregated volume of publications, we find an inverted power law with an exponent that is in many cases near 2 . Lotka's law is an empirical law with authors as the basic unit of analysis. It is one of the fundamental bibliometric laws that, relatively speaking, can be easily tested against very different bibliometric samples, which explains its overwhelming success. Researchers have discussed how collaboration influences productivity (e.g. Kretschmer and Kretschmer 2007) and how productivity patterns change between different generations of researchers (e.g. Fronczak et al. 2007). But Lotka's law is more than just a statistical regularity. It belongs to a class of mathematical distributions that are characteristic of complex processes not only in social systems, but also in natural systems (Bak 1996). For information processes, even the label of "Lotkaian informetrics" has been used by Egghe in his systematic mathematical analysis of functions used to describe Lotka's law. Lotka's mathematical model is a descriptive one. But it can be used as a litmus test for any predictive model of scientific activity that also entails scientists and publications. For instance, in his agent-based model, through which topics, papers and authors find each other and form scientific fields, Gilbert (1997) calculated Lotka's law to see if his artificial science simulation reveals structures similar to real science.

Details about Lotka's law are given in Chap. 3 of this book. The emphasis here is on its diffusion through the years, the applications of the law, and the characteristics 


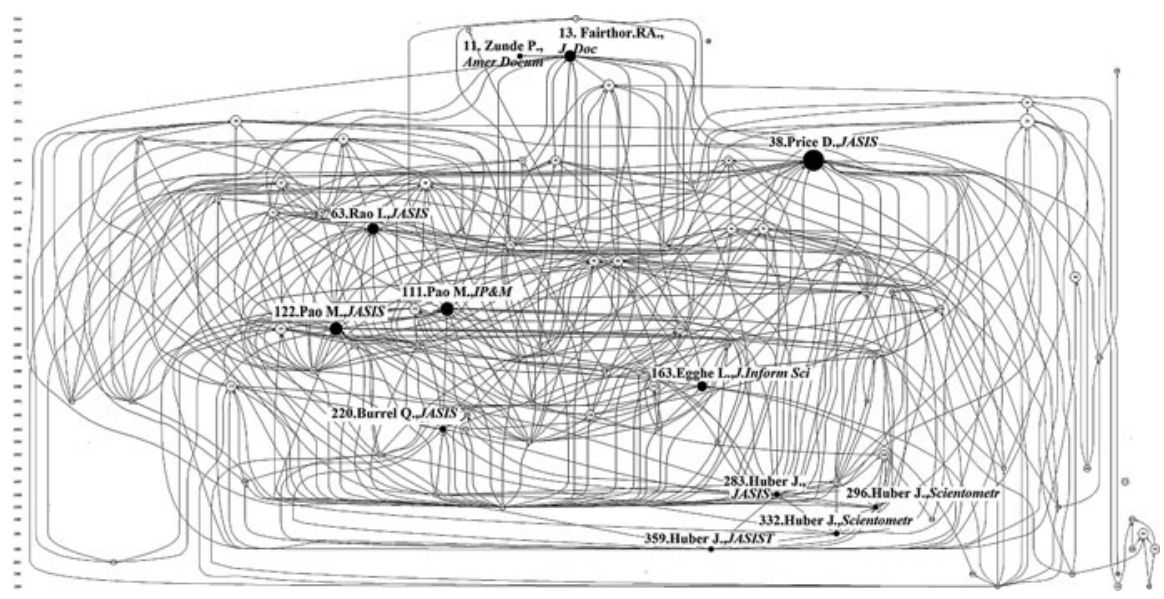

Fig. 2.11 Historiograph of documents citing Lotka's law and main path

of those documents citing it. A total of 612 documents cite "The frequency distribution of scientific productivity," Alfred Lotka's 1926 paper published in the Journal of the Washington Academy of Sciences. The number of publications dealing with the informetric law of the skewed distribution of publications is so large that it is possible to verify Lotka's law using a set of papers devoted to his law of scientific productivity (Yablonsky 1980).

The reconstruction of the diffusion trajectories of Lotka using HistCite ${ }^{\mathrm{TM}}$ (see Fig. 2.10, right) illustrates cohesiveness in the set: authors citing Lotka are also both aware of each other and citing each other. Figure 2.10 also gives an impression of the size and density of the network of papers citing Lotka's paper of 1926 (the graph is not displayed for detailed inspection ${ }^{5}$ ). Lotka's law is cited in more than 200 different journals, but more than $50 \%$ of them correspond to the ISI subject category of Library and Information Science. This way, the graph also reflects the dominance of Scientometrics as part of LIS disciplines inside the set. The graph illustrates how Lotka's law becomes a relevant "knowledge item" that binds papers together in the flows of information and knowledge production and that contributes to a consolidation of scientometrics as a scientific field, for which a high connectivity of networks of citations is one important feature. For a slightly more detailed inspection, we reproduce the historiograph using as a threshold at least five citations from other documents of the set (91 nodes).

In Fig. 2.11, the nodes of the main path or backbone are highlighted and labeled. There is an important volume of documents that either refers to Lotka's formula in a more rhetorical way or discusses mechanisms for and implications of this law in the light of social theories. But most of the documents highlighted by the main path

\footnotetext{
${ }^{5} \mathrm{We}$ will provide a on-line version for detailed inspection.
} 
Table 2.3 Main path of documents citing Lotka

\begin{tabular}{|c|c|c|c|}
\hline $\begin{array}{l}\text { First } \\
\text { Author }\end{array}$ & PY & Journal & Title \\
\hline Zunde, $\mathrm{P}$ & 1969 & JASIST & Indexing consistency and quality \\
\hline Fairthor, RA & 1969 & J.DOC. & $\begin{array}{l}\text { Progress in documentation - } \\
\text { empirical hyperbolic } \\
\text { distributions } \\
\text { (Bradford-Zipf-Mandelbrot) } \\
\text { for bibliometric description } \\
\text { and prediction }\end{array}$ \\
\hline Price, DJD & 1976 & JASIST & $\begin{array}{l}\text { General theory of bibliometric and } \\
\text { other cumulative advantage } \\
\text { processes }\end{array}$ \\
\hline Rao, IKR & 1980 & JASIST & $\begin{array}{l}\text { Distribution of scientific } \\
\text { productivity and social-change }\end{array}$ \\
\hline Pao, ML & 1985 & IP\&M & Lotka law - a testing procedure \\
\hline Pao, ML & 1986 & JASIS & $\begin{array}{l}\text { An empirical-examination of } \\
\text { Lotka law }\end{array}$ \\
\hline Egghe, L & 1990 & $\begin{array}{l}\text { J. INFORMATION } \\
\text { SCIENCE }\end{array}$ & $\begin{array}{l}\text { The duality of informetric systems } \\
\text { with applications to the } \\
\text { empirical laws }\end{array}$ \\
\hline Burrell, Q1 & 1993 & JASIST & $\begin{array}{l}\text { Yes, the GIGP really does work - } \\
\text { and is workable }\end{array}$ \\
\hline Huber, JC & 1998 & JASIST & $\begin{array}{l}\text { Cumulative advantage and } \\
\text { success-breeds-success: the } \\
\text { value of time pattern analysis }\end{array}$ \\
\hline Huber, JC & 1999 & SCIENTOMETRICS & $\begin{array}{l}\text { Inventive productivity and the } \\
\text { statistics of exceedances }\end{array}$ \\
\hline Huber, JC & 2001 & SCIENTOMETRICS & $\begin{array}{l}\text { Scientific production: a statistical } \\
\text { analysis of authors in } \\
\text { mathematical logic }\end{array}$ \\
\hline Huber, JC & 2002 & JASIST & $\begin{array}{l}\text { A new model that generates } \\
\text { Lotka's law }\end{array}$ \\
\hline
\end{tabular}

of Fig. 2.11 (dark circles) entail mathematical formulations or applications (e.g., for descriptive statistics of research fields, journals, or specific regions or countries). Most of the documents using Lotka's law rely on empirical data at a meso level of aggregation (101-10,000 records). A bibliographic description of the documents belonging to the main path is available in Table 2.3. Most of these papers discuss Lotka's law in the context of specific distribution functions and stochastic processes that lead to them.

\subsubsection{The Case of Modeling the Spreading of Ideas as a Disease - W. Goffman}

Goffman's model describes the spreading out of an idea as analogous to the spreading of a disease. Similar to Lotka's law, which is part of the long history in 
the study of statistical distributions, the epidemic model Goffman adopted has a long history. In 1927, Kermack and McKendrick published a mathematical model that is still known as the SIR model. This model describes the spreading out of a disease in terms of the relative growth of three subpopulations: the number of susceptible but uninfected individuals ( $\mathrm{S}$ ), the number of infected individuals (I) who carry the disease and can spread it further to the S-group, and the number of recovered individuals $(\mathrm{R})$ who cannot be reinfected again. Obviously, the growth of infected individuals depends on the number of available susceptible individuals and is slowed down by recovering. Goffman applied this idea to science. The number of "infected" researchers represents the researchers working at an idea or in a field. The R-group has lost interest and the S-group forms the reservoir for further growth. Unlike Lotka's law, for which only one key publication can be found, Goffman published work about this model over the course of several years, and also with different coauthors (Harmon 2008). For our analysis, we identified two main publications that still gain sufficient recognition.

Goffman's model entails many more variables (three instead of one) and many more parameters than Lotka's law. Although it has been tested empirically (Wagner-Döbler 1999), the number of "susceptible" researchers is not easy to estimate (Burger and Bujdoso 1985). Nevertheless, one prediction of Goffman's model can easily be measured: the growth of a scientific field. Scientometrics has produced a large amount of growth studies of new scientific fields. Correspondingly, the literature about growth laws in science also makes references to Goffman's model as one possible explanation of such observed growth curves (Tabah 1999). Consequently, Goffman's model has been extended - from the growth of one field (based on the interaction of researchers at three different stages) to the growth of a group of fields (Bruckner et al. 1990). It has also been extended from a group-based model, where the probability of being "infected" with an idea is the same for each subgroup member, to a network-based model, in which the concrete transmission path and the topology of all possible contacts matter (Bettencourt et al. 2009; Lambiotte and Panzarasa 2009).

This history of perception is visible in the main path of the HistCite ${ }^{\mathrm{TM}}$ graph (darker nodes in Fig. 2.12). The 73 citing documents are published in 47 journals illustrating a much more dispersed trajectory of diffusion. Although the Goffman epidemic model is known in the scientometric community, the participation of Library and Information Science journals among the documents citing the seed papers is never as relevant as was the case for Lotka's law.

The main-path analysis also reveals that there is nearly 10 -year between the documents in the main path, meaning that once in a decade a paper appears that reminds us of or reviews epidemic models and related approaches (Table 2.4). Beginning in 2000, however, the situation changes. Works by Bettencourt et al. (2008, 2009), and later Lambiotte et al. (2009), mark the emergence of the theory of complex-networks in statistical physics (Scharnhorst 2003; Pyka and Scharnhorst 2009). This represents a solid hype, in which new attention from physicists was drawn to the science system. 
Table 2.4 Main path of documents citing Goffman

\begin{tabular}{|c|c|c|c|}
\hline $\begin{array}{l}\text { First } \\
\text { Author }\end{array}$ & PY & Journal & Title \\
\hline Bujdoso, E & 1982 & J. RADIOANAL CHEM & $\begin{array}{l}\text { Prompt nuclear analysis - growth and } \\
\text { trends - a scientometric study }\end{array}$ \\
\hline Bruckner, E & 1990 & SCIENTOMETRICS & $\begin{array}{l}\text { The application of evolution models } \\
\text { in scientometrics }\end{array}$ \\
\hline Wilson, CS & 1999 & $\begin{array}{l}\text { ANNUAL REVIEW OF } \\
\text { INFORMATION } \\
\text { SCIENCE AND } \\
\text { TECHNOLOGY }\end{array}$ & Informetrics \\
\hline Tabah, AN & 1999 & $\begin{array}{l}\text { ANNUAL REVIEW OF } \\
\text { INFORMATION } \\
\text { SCIENCE AND } \\
\text { TECHNOLOGY }\end{array}$ & $\begin{array}{l}\text { Literature dynamics: studies on } \\
\text { growth, diffusion, and epidemics }\end{array}$ \\
\hline $\begin{array}{l}\text { Bettencourt, } \\
\text { LMA }\end{array}$ & 2006 & PHYSICA A & $\begin{array}{l}\text { The power of a good idea: } \\
\text { Quantitative modeling of the } \\
\text { spread of ideas from } \\
\text { epidemiological models }\end{array}$ \\
\hline $\begin{array}{l}\text { Bettencourt, } \\
\text { LMA }\end{array}$ & 2008 & SCIENTOMETRICS & $\begin{array}{l}\text { Population modeling of the } \\
\text { emergence and development of } \\
\text { scientific fields }\end{array}$ \\
\hline Lambiotte, $\mathrm{R}$ & 2009 & $\begin{array}{l}\text { JOURNAL OF } \\
\text { INFORMETRICS }\end{array}$ & $\begin{array}{l}\text { Communities, knowledge creation, } \\
\text { and information diffusion }\end{array}$ \\
\hline Chen, CM & 2009 & $\begin{array}{l}\text { JOURNAL OF } \\
\text { INFORMETRICS }\end{array}$ & $\begin{array}{l}\text { Towards an explanatory and } \\
\text { computational theory of scientific } \\
\text { discovery }\end{array}$ \\
\hline $\begin{array}{l}\text { Bettencourt, } \\
\text { LMA }\end{array}$ & 2009 & $\begin{array}{l}\text { JOURNAL OF } \\
\text { INFORMETRICS }\end{array}$ & $\begin{array}{l}\text { Scientific discovery and topological } \\
\text { transitions in collaboration } \\
\text { networks }\end{array}$ \\
\hline
\end{tabular}

The science system is a social system for which large (digital) data sets are available. These sets entail a lot of relational information from which different networks can be built and analyzed (Havemann 2009). At the moment, the complexnetworks community has shifted its focus from analyzing the structure (as the logical first step of a statistical analysis) to examining the evolution of the network structure (Pastor-Satorras and Vespignani 2004), and further to studying dynamic processes on complex-network topologies. Epidemic modeling has experienced an important revival, and it has been accompanied by a revival of epidemic models of science. The new network science has also influenced the reception of our last case.

\subsubsection{Network Dynamics from Science and Beyond - Derek de Solla Price}

Derek de Solla Price is considered one of the pioneers in the field of Scientometrics. He has written about many different topics, and his work is still highly cited in the scientometric community. In 1965, he published a relatively short paper in the journal Science entitled "Networks of papers." Although this paper 


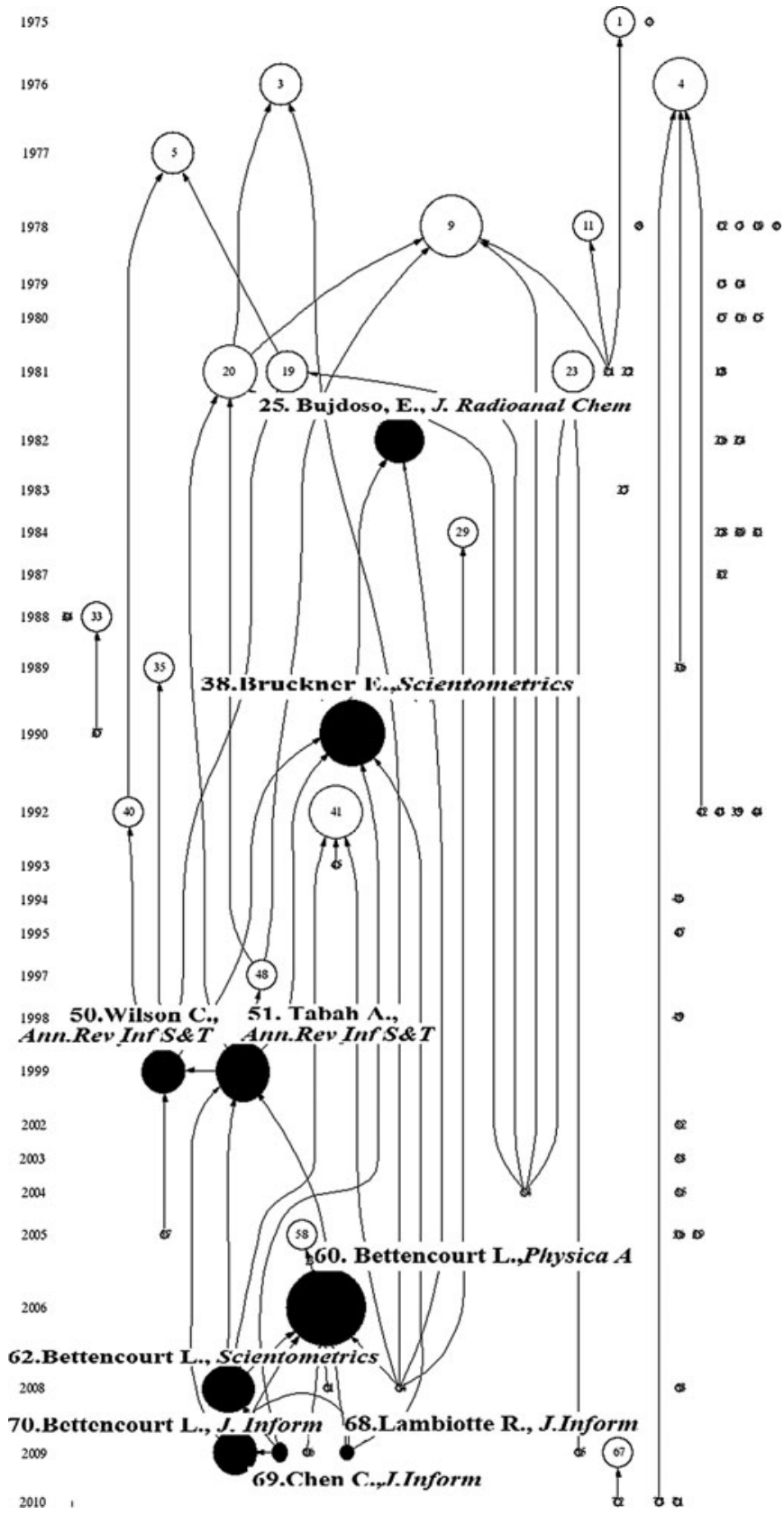

Fig. 2.12 Historiograph of documents citing Goffman's epidemic model 


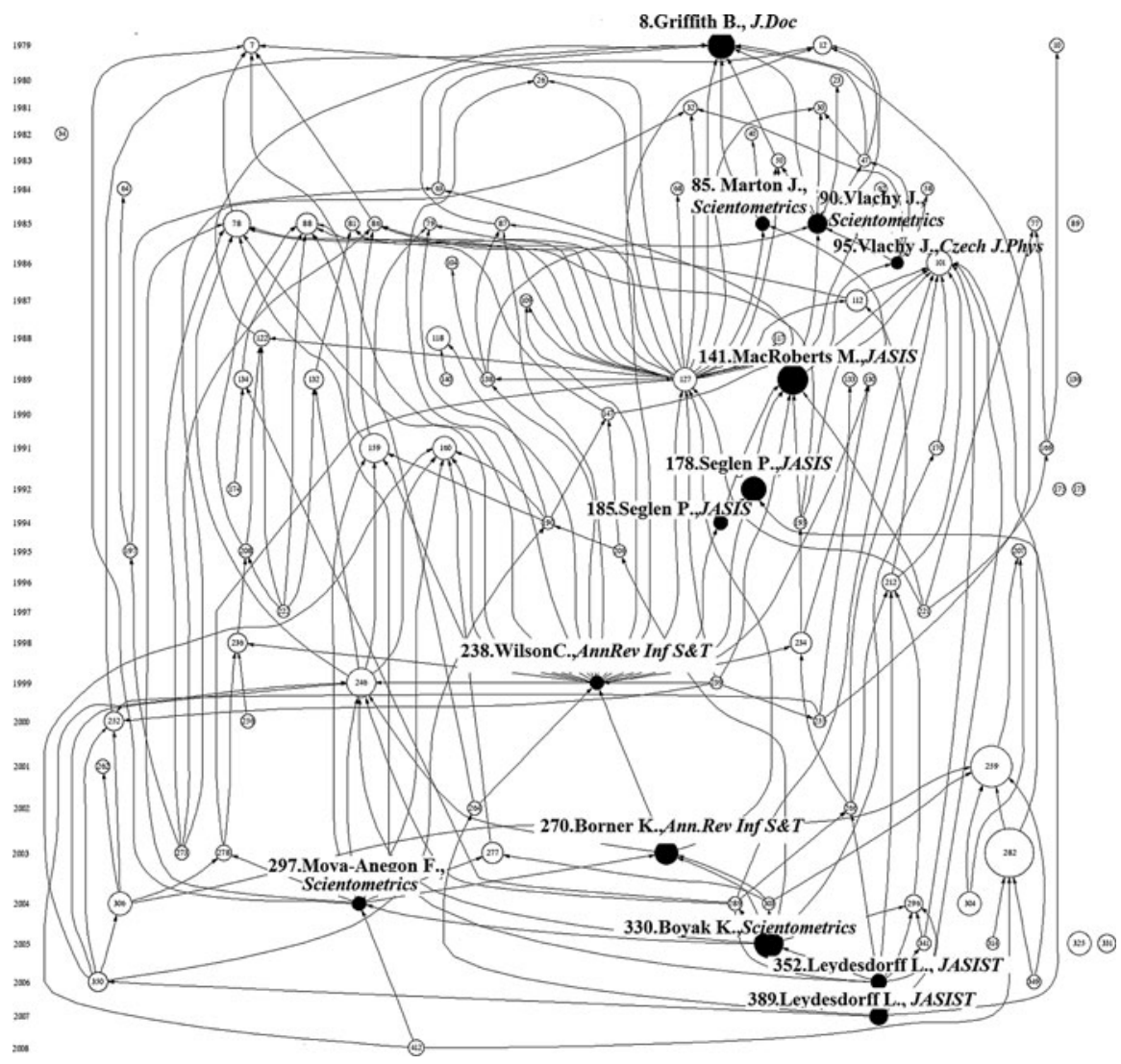

Fig. 2.13 Historiograph of documents citing Price's network model of scientific papers and main path

contains only a few formulas, it has established a foundation for further study of scientific communication, including mathematical models. Price begins his paper with the observation that citations are skewed in their distribution. He examines the consequences of the (exponential) growth of publications (one of his other major findings) for the future distribution of citations, and he argues that although references and citations form a balance, their distribution over papers differs fundamentally. Citations are not homogeneously distributed over the growing body of literature. Instead, they cluster in time and space (defined as sets of papers). Based on these structures, we can identify research fronts. Citing is the recursive and constitutive process that redefines, reshapes, and re-creates scientific knowledge for each generation of scholars. Price visualizes the evolution of networks of papers. He not only reflects upon fundamental bibliographic questions such as classification, he also points to a number of unknown or unclear characteristics of the self-organized, collective process of references, later addressed by measurements and models. 
Table 2.5 Main path of documents citing Price

\begin{tabular}{|c|c|c|c|}
\hline $\begin{array}{l}\text { First } \\
\text { Author }\end{array}$ & PY & Journal & Title \\
\hline Griffith, BC & 1979 & J.DOC & $\begin{array}{l}\text { Aging of scientific literature - } \\
\text { citation analysis }\end{array}$ \\
\hline Vlachy, J & 1985 & SCIENTOMETRICS & $\begin{array}{l}\text { Citation histories of scientific } \\
\text { publications - the data sources }\end{array}$ \\
\hline Marton, J & 1985 & SCIENTOMETRICS & $\begin{array}{l}\text { Obsolescence or immediacy - } \\
\text { evidence supporting Price } \\
\text { hypothesis }\end{array}$ \\
\hline Vlachy, J & 1986 & CZECH J PHYSICS & $\begin{array}{l}\text { Scientometric analyses in physics - } \\
\text { where we stand }\end{array}$ \\
\hline $\begin{array}{l}\text { Macroberts, } \\
\text { BR }\end{array}$ & 1989 & JASIST & $\begin{array}{l}\text { Problems of citation analysis - a } \\
\text { critical review }\end{array}$ \\
\hline Seglen, PO & 1992 & JASIST & The skewness of science \\
\hline Seglen, PO & 1994 & JASIST & $\begin{array}{l}\text { Causal relationship between article } \\
\text { citedness and journal impact }\end{array}$ \\
\hline Wilson, CS & 1999 & $\begin{array}{l}\text { ANNUAL REVIEW OF } \\
\text { INFORMATION } \\
\text { SCIENCE AND } \\
\text { TECHNOLOGY }\end{array}$ & Informetrics \\
\hline Borner, K & 2003 & $\begin{array}{l}\text { ANNUAL REVIEW OF } \\
\text { INFORMATION } \\
\text { SCIENCE AND } \\
\text { TECHNOLOGY }\end{array}$ & Visualizing knowledge domains \\
\hline $\begin{array}{l}\text { Moya- } \\
\text { Anegon, F }\end{array}$ & 2004 & SCIENTOMETRICS & $\begin{array}{l}\text { A new technique for building maps } \\
\text { of large scientific domains } \\
\text { based on the cocitation of } \\
\text { classes and categories }\end{array}$ \\
\hline Boyack, KW & 2005 & SCIENTOMETRICS & Mapping the backbone of science \\
\hline Leydesdorff, L & 2006 & JASIST & $\begin{array}{l}\text { Can scientific journals be classified } \\
\text { in terms of aggregated } \\
\text { journal-journal citation relations } \\
\text { using the journal citation } \\
\text { reports? }\end{array}$ \\
\hline Leydesdorff, L & 2007 & JASIST & $\begin{array}{l}\text { Betweenness centrality as an } \\
\text { indicator of the } \\
\text { interdisciplinarity of scientific } \\
\text { journals }\end{array}$ \\
\hline
\end{tabular}

Due to Price's overall relevance to the scientometric community and his rich trajectory of published papers relevant to this field, documents citing Price's network model are mostly published in journals of Library and Information Science. This is similar to the case of Lotka's law. In Price's case, we also present the HistCite ${ }^{\mathrm{TM}}$ graph for visual inspection (Fig. 2.13).

The historiograph shown in Fig. 2.13 illustrates a cohesive set of documents similar to the case of Lotka's law. However, the authors citing Price do not possess the same awareness of each other as was for the case for authors using the Lotka model. For this reason, it was possible to lower the threshold used in Lotka's case 
(citing at least five other documents) to all those documents citing at least three other documents (96 nodes). The network is less dense, justifying a lower threshold. The documents in the main path (dark labeled nodes in Fig. 2.13) are detailed in Table 2.5.

A comparison of the backbone of Lotka and Price reinforces the impression that comes with an inspection of all journals in the two data sets. Both authors and both models are part of the knowledge base of scientometrics and are fully embraced by the community. This can still not be said for Goffman, however.

\subsection{Concluding Remarks}

To a certain extent, the analysis from present to past and from past to present complement each other. We found empirical evidence for the narrative drawn at the beginning of this chapter. In particular, the scattered and partly isolated nature of mathematical approaches could be made visible with the help of citation analysis. We found different schools or threads of mathematical approaches and models in a wide sense in LIS - led by statistical analysis and stochastic processes. But although they all draw on a more widely connected network of mathematical approaches, they do not communicate this among each other. We also found evidence for the still relatively marginal role of dynamic models in the set of current papers in LIS, as well as in the way Goffman (as one of the proponents of dynamic models) is hardly recognized in the LIS community.

Concerning the relation between predictive and descriptive models of science, which is one of the topics addressed by this book (see in particular Chap. 1), our empirical analysis underlines once more that when mathematical models are currently applied to describe the development of science at all, they rather focus on an analysis of the current state in a descriptive way. However, each mathematical model with a dynamic component also has the potential to be applied for prediction. Let us give an example: Lotka's law of productivity is just a mathematical function between variables (number of scientists, number of their publications) that can be empirically tested. This means it is predictive in its essence. However, any stochastic process proposed to explain the establishment of Lotka's law as a quasi-stationary distribution of a dynamic process makes assumptions about micromechanisms of behavior. One possible assumption is that the probability of producing an additional article depends on the number of articles an author has already produced. Such a rule can be implemented in models explicitly designed to test the collective outcome of behavioral rules on the level of individuals (such as Gilbert's model). We can also use such assumptions about micromechanisms and the parameters of Lotka's law to predict the productivity of a certain scientific community. However, only a few attempts have been made to turn mathematical models of science into predictive models for scientific development (see Fronczak et al. 2007). This may have more to do with the actual focus of research agendas than the potential of mathematical models as such. 
When talking about "predictive modeling," what is often expressed is the wish to forecast a new idea or a new field. However, in the history of mathematical models of science, one of the predictive models in posse (Goffman's epidemic model) has been mainly applied in esse to the history of scientific fields (e.g., (Wagner-Döbler 1999)). There are two reasons for this apparent mismatch. First, innovative ideas and new fields representing "real" breakthroughs cannot be predicted by definition. Otherwise, there would not be structural changes of the whole science system, only minor alterations of existing knowledge. Now, what can be predicted also depends on how we define innovation and new ideas. We might reasonably be able to suggest the directions of incremental scientific progress, but not (as said before) radical innovations. In this respect, predictive models are condemned to fail. Peter Allen used to express it in this way: "The more 'credible' predictions are, the more likely they are to NOT happen" (Cited in Ebeling and Scharnhorst (2009)).

Yet, while models might fail to predict actual innovations, they have a great and often overlooked potential to analyze the circumstances under which innovations new ideas and new fields emerging independently of their essence - will most likely arise. Only some of the modeling attempts in the past figuring in our analysis have discussed this aspect (Bruckner et al. 1990). Understood in this way, the potential of models to predict "innovative sciences" - their collaboration pattern, their selection mechanisms, their institutional frames, and so on - is unlimited, and still unexplored. Within such a frame, both descriptive (or, better, statistical) models and predictive (or, better, dynamical) models can be applied. The first can depict characteristics of successful science in the past and search for similar patterns in the present; the second can formulate hypotheses about mechanisms for successful science, test them empirically in the past, and shape them for the present by means of science policy.

Having pointed to this need of modeling for forecasting conditions of events rather than the events themselves, we immediately have to admit that differentiating and tracing such a use of mathematical models is almost impossible by the analysis of citations only. Again, citation analysis can point us to interesting areas to look at more closely. But for the actual use, application, and interpretation of models, we either have to rely on manual inspection or on other kind of references that relate a model to a certain use. That seems to be even harder to trace semi-automatically than the pure appearance of mathematical models.

What we have done in this analysis is to describe the current state of diffusion of mathematical modeling ideas irrespectively of their actual use. Already, this confronted us with a lot of problems. To trace an adoption pattern as sketched in Fig. 2.1, we would need to be able to automatically extract all documents (across all disciplines) that address the application of the mathematical models to the science system. Moreover, we would also like to see in parallel the bibliometric traces of the mathematical branches feeding these models. However, there is no consistent indexing of documents (outside of knowledge-domain-specific databases) concerning the methods they apply. We also found that there is no term-keyword-subject combination that delivers a specific enough set of documents for mathematical models in science over the whole Web of Science database. This is why we have 
chosen the combination of tracing known model approaches to science (over all disciplines) with screening a set of established LIS journals for the appearance of mathematical modeling.

Despite this limited-sampling approach and specific-citation perspective, we found evidence both for the relatively isolated existence of mathematical modeling and its implicit commonly shared knowledge base. We also saw the influence of developments in other fields on the implementation of new methods in LIS. The emergence of the so-called new network science (Barabási 2002) and the interest from statistical physics and, in a wider sense, complexity research (all three representing the mother disciplines for dynamic processes) do not remain without resonance in scientometrics. Partly, we observe a diffusion of new researchers; partly, we also observe a taking up of themes and methods by established scientometricians who in some way received their primary academic forming in natural sciences and mathematics.

Our experiments show that developments in scientometrics cannot be understood from an inner-situated perspective only. The use of mathematical dynamic models to describe the sciences is not restricted to LIS journals. Actually, some interesting developments in this area take place at very different locations, such as in journals of computational philosophy (see Chap. 4 of this book), sociology (see Chap. 6 of this book), and physics. But the universal nature of mathematical dynamic approaches their variety in methods and topics addressed - makes it impossible to set up a string of keywords with which one can easily extract a good sample of mathematical models applied to the science system. The same holds for a past-to-present analysis. Mathematical models applied to science can pop up in all places. We selected three researchers - Lotka, Goffman, and Price - who performed pioneering work relevant to scientometrics, who have been interested in dynamic processes, and who have developed mathematical models and/or ideas that have been central for modeling. There might be many other researchers who have done interesting modeling experiments and might only be rediscovered by chance. But even for our three "landmark" scholars, it is not easy for us to pick one publication from their oeuvre that fully represents their "science model" and nothing else. The work of an individual scholar is like a journey through a landscape of science. Partly discovering the existing landscape for her/himself and partly creating this landscape, the scholar leaves marks and traces and is marked and imprinted by their journey. One might argue that there is a certain arbitrariness in the selection of our cases and the seed nodes for the historiographic methods. Indeed, we are aware of this. We do not claim comprehensiveness; instead, we aim for an insightful illustration of the complexity of knowledge and model transfer in science. Our practical problems in the selection of samples also reflect a more fundamental problem.

The diffusion of ideas and methods across the sciences is a combination of the progress of knowledge inside specialties and a diffusion of knowledge between specialties in which knowledge is not just transmitted but also altered. The evolution of knowledge entails processes of specification as well as generalization. Correspondingly, in the cognitive and social space, specialties and invisible colleges emerge and disappear, merge and split up, take form, stabilize, transform, and 


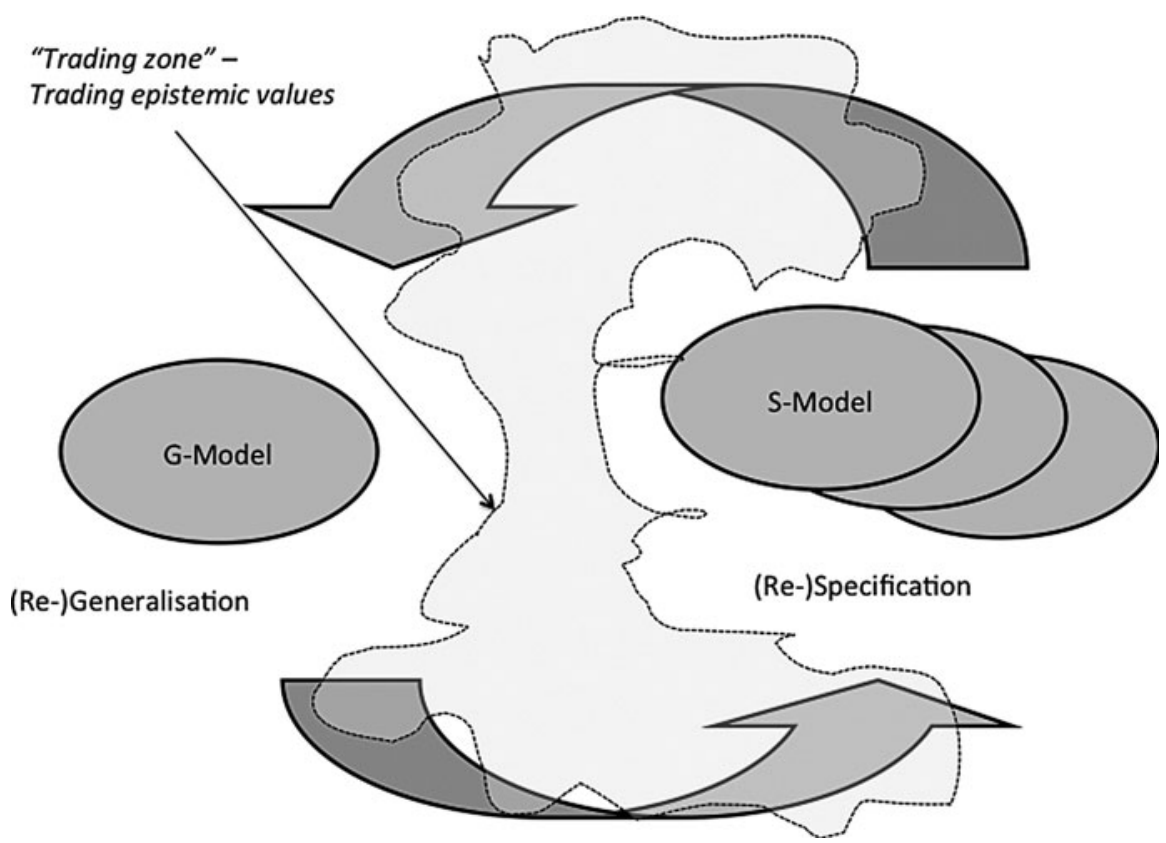

Fig. 2.14 Models travelling between generic and specific levels

pass different stages of life cycles, all based on a constant flow of creation and recombination of elementary units of knowledge. This eternal flow also influences the travel of mathematical models. Approaches to mathematical modeling can emerge on a generic mathematical level or inside of a specialty or knowledge domain. Independently from where they appear first, they are embedded in a cycle of (re)generalization and (re)specification (Fig. 2.14). One of these special fields can be scientometrics. Mathematical models can be developed specifically for science. However, they will always share a generic structural element with other models and contribute to this pool. On the other side, from the general pool of models they can expect entries of new model ideas along all possible lines of mathematical modeling. Mathematical models and approaches to science can be the result of applying different mathematical approaches that have been used in other disciplines. For example, some models using entropy statistics stem from the Mathematical Theory of Communications, which originally addressed an engineering problem but which has been applied in more social sciences like economics.

This feature of the model-building process - the cycle between generalization and specification - makes it very complicated to trace a model transfer bibliometrically. It also makes it hard to produce an overview of possible dynamic models of science, which in principle encompass all dynamic modeling approaches.

Therefore, we applied a practical approach by concentrating on LIS journals for the analysis of the present situation and by depicting a few "classics" from the past. 
The combination of both approaches provides bibliometric evidence for less cited mathematical approaches that have been fading away, for models that have been only recently (re)discovered, and for a shared underlying cognitive reference space that is not always visible in direct citations. Our study also illustrates the process of spreading new ideas and demonstrates how these can eventually converge. It can be expected that such a historiographic study can be used as a departure point for an evaluation of certain mathematical models. What are the characteristics of the most successful models? Do they tend to be more universal or domain specific? Are they multi-leveled? We can also imagine applying some of the characteristics of models discussed in the Introduction Chapter in a future analysis. For instance, one could ask about the quantitative or qualitative nature of the models applied, the type of behavior in science targeted, and the representation used for results.

Last but not least, one remark. In our historic narrative at the beginning of this chapter, we argued that eventually there need to be researchers who are intrigued and curious enough to test mathematical models. However, while researchers as the source of ideas remain utterly important, mathematical modeling will still remain ephemeral if it is to be an activity driven by curiosity and not by demand. The creativity of the human imagination is triggered by curiosity as well as by a societal demand for a certain type of knowledge, method, and models. There is no sustainable modeling without a thorough theoretical foundation, and, in this respect, models should be mainly guided by theory.

One could argue that, compared to other fields and disciplines, scientometrics is a relatively young field and has therefore not yet penetrated or been open to complex models very much. But dynamic modeling of the science system will not emerge if there is not a need to apply relatively complex, computational-intensive models that also require diverse collaborations. The pertinent growth of the science system, the scarcity of resources (human and material), and the increasing complexity that requires other mechanisms of control might all be decisive in triggering a collective action for Modeling Science Dynamics.

\section{Appendix 1: Papers Using Mathematical Approaches to Understand the Science System (Fig. 2.1)}

Table 2.6 Statistics of the search: Present to past

\begin{tabular}{lll}
\hline Node & Bibliographic metadata & Times cited \\
\hline 1 & Torvik VI, 2005, J AM SOC INF SCI TECHNOL, V56, P140 & 18 \\
2 & Xekalaki E, 2005, SCIENTOMETRICS, V62, P293 & 1 \\
3 & Santos JB, 2005, SCIENTOMETRICS, V62, P329 & 2 \\
4 & Simkin MV, 2005, SCIENTOMETRICS, V62, P367 & 8 \\
5 & Bailon-Moreno R, 2005, SCIENTOMETRICS, V63, P231 & 1 \\
\hline
\end{tabular}


Table 2.6 (continued)

\begin{tabular}{|c|c|c|}
\hline Node & Bibliographic metadata & Times cited \\
\hline$\overline{6}$ & Egghe L, 2005, J AM SOC INF SCI TECHNOL, V56, P664 & 2 \\
\hline 7 & Egghe L, 2005, J AM SOC INF SCI TECHNOL, V56, P669 & 8 \\
\hline 8 & Sombatsompop N, 2005, J AM SOC INF SCI TECHNOL, V56, P676 & 15 \\
\hline 9 & Matia K, 2005, J AM SOC INF SCI TECHNOL, V56, P893 & 10 \\
\hline 10 & Egghe L, 2005, J AM SOC INF SCI TECHNOL, V56, P935 & 13 \\
\hline 11 & Efron M, 2005, J AM SOC INF SCI TECHNOL, V56, P969 & 4 \\
\hline 12 & Liang LM, 2005, J AM SOC INF SCI TECHNOL, V56, P1045 & 10 \\
\hline 13 & Burrell QL, 2005, SCIENTOMETRICS, V64, P247 & 5 \\
\hline 14 & Morris SA, 2005, J AM SOC INF SCI TECHNOL, V56, P1250 & 5 \\
\hline 15 & Burrell QL, 2005, INFORM PROCESS MANAGE, V41, P1317 & 8 \\
\hline 16 & Egghe L, 2005, INFORM PROCESS MANAGE, V41, P1330 & 2 \\
\hline 17 & Shan S, 2005, INFORM PROCESS MANAGE, V41, P1369 & 2 \\
\hline 18 & Lafouge T, 2005, INFORM PROCESS MANAGE, V41, P1387 & 3 \\
\hline 19 & Payne N, 2005, INFORM PROCESS MANAGE, V41, P1495 & 1 \\
\hline 20 & Coccia M, 2005, SCIENTOMETRICS, V65, P307 & 0 \\
\hline 21 & Burrell QL, 2005, SCIENTOMETRICS, V65, P381 & 11 \\
\hline 22 & Dominich S, 2006, INFORM PROCESS MANAGE, V42, P1 & 0 \\
\hline 23 & Zuccala A, 2006, J AM SOC INF SCI TECHNOL, V57, P152 & 14 \\
\hline 24 & Aksnes DW, 2006, J AM SOC INF SCI TECHNOL, V57, P169 & 13 \\
\hline 25 & Klavans R, 2006, J AM SOC INF SCI TECHNOL, V57, P251 & 33 \\
\hline 26 & Ackermann E, 2006, SCIENTOMETRICS, V66, P451 & 0 \\
\hline 27 & Martens BVD, 2006, J AM SOC INF SCI TECHNOL, V57, P330 & 1 \\
\hline 28 & Chen CM, 2006, J AM SOC INF SCI TECHNOL, V57, P359 & 67 \\
\hline 29 & van Raan AFJ, 2006, J AM SOC INF SCI TECHNOL, V57, P408 & 21 \\
\hline 30 & Choi J, 2006, INFORM PROCESS MANAGE, V42, P331 & 5 \\
\hline 31 & Wei CP, 2006, INFORM PROCESS MANAGE, V42, P350 & 12 \\
\hline 32 & Izsak J, 2006, SCIENTOMETRICS, V67, P107 & 2 \\
\hline 33 & Yoo SH, 2006, SCIENTOMETRICS, V69, P57 & 0 \\
\hline 34 & Egghe L, 2006, SCIENTOMETRICS, V69, P121 & 67 \\
\hline 35 & Glanzel W, 2006, SCIENTOMETRICS, V67, P315 & 73 \\
\hline 36 & Burrell QL, 2006, SCIENTOMETRICS, V67, P323 & 0 \\
\hline 37 & Rousseau R, 2006, J AM SOC INF SCI TECHNOL, V57, P1404 & 2 \\
\hline 38 & Burrell QL, 2006, J AM SOC INF SCI TECHNOL, V57, P1406 & 4 \\
\hline 39 & Samoylenko I, 2006, J AM SOC INF SCI TECHNOL, V57, P1461 & 7 \\
\hline 40 & Peng D, 2006, SCIENTOMETRICS, V69, P271 & 0 \\
\hline 41 & Roth C, 2006, SCIENTOMETRICS, V69, P429 & 5 \\
\hline 42 & Mingers J, 2006, INFORM PROCESS MANAGE, V42, P1451 & 6 \\
\hline 43 & Zitt M, 2006, INFORM PROCESS MANAGE, V42, P1513 & 17 \\
\hline 44 & Su Y, 2006, J AM SOC INF SCI TECHNOL, V57, P1977 & 0 \\
\hline 45 & Van Den Besselaar P, 2006, SCIENTOMETRICS, V68, P377 & 10 \\
\hline 46 & Borner K, 2006, SCIENTOMETRICS, V68, P415 & 8 \\
\hline 47 & Klavans R, 2006, SCIENTOMETRICS, V68, P475 & 15 \\
\hline 48 & Small H, 2006, SCIENTOMETRICS, V68, P595 & 23 \\
\hline 49 & Contreras C, 2006, SCIENTOMETRICS, V69, P689 & 3 \\
\hline 50 & Kretschmer H, 2007, J INFORMETR, V1, P308 & 1 \\
\hline 51 & Jarneving B, 2007, J INFORMETR, V1, P338 & 0 \\
\hline 52 & Burrell QL, 2007, J INFORMETR, V1, P16 & 22 \\
\hline
\end{tabular}


Table 2.6 (continued)

\begin{tabular}{|c|c|c|}
\hline Node & Bibliographic metadata & Times cited \\
\hline 53 & Leydesdorff L, 2007, J AM SOC INF SCI TECHNOL, V58, P25 & 14 \\
\hline 54 & McDonald JD, 2007, J AM SOC INF SCI TECHNOL, V58, P39 & 4 \\
\hline 55 & Koike A, 2007, J AM SOC INF SCI TECHNOL, V58, P51 & 2 \\
\hline 56 & Egghe L, 2007, J AM SOC INF SCI TECHNOL, V58, P452 & 29 \\
\hline 57 & Na SH, 2007, INFORM PROCESS MANAGE, V43, P302 & 1 \\
\hline 58 & Lucio-Arias D, 2007, SCIENTOMETRICS, V70, P603 & 3 \\
\hline 59 & Egghe L, 2007, J INFORMETR, V1, P115 & 5 \\
\hline 60 & Shibata N, 2007, J AM SOC INF SCI TECHNOL, V58, P872 & 2 \\
\hline 61 & Zitt M, 2007, INFORM PROCESS MANAGE, V43, P834 & 0 \\
\hline 62 & Zhao DZ, 2007, J AM SOC INF SCI TECHNOL, V58, P1285 & 2 \\
\hline 63 & Rousseau R, 2007, J AM SOC INF SCI TECHNOL, V58, P1551 & 3 \\
\hline 64 & Nadarajah S, 2007, SCIENTOMETRICS, V72, P291 & 1 \\
\hline 65 & Simkin MV, 2007, J AM SOC INF SCI TECHNOL, V58, P1661 & 6 \\
\hline 66 & Morris SA, 2007, J AM SOC INF SCI TECHNOL, V58, P1764 & 4 \\
\hline 67 & Bornmann L, 2007, SCIENTOMETRICS, V73, P139 & 1 \\
\hline 68 & de Moya-Anegon F, 2007, J AM SOC INF SCI TECHNOL, V58, P2167 & 9 \\
\hline 69 & Lariviere V, 2008, J AM SOC INF SCI TECHNOL, V59, P288 & 12 \\
\hline 70 & van Raan AFJ, 2008, J AM SOC INF SCI TECHNOL, V59, P565 & 7 \\
\hline 71 & Bornmann L, 2008, J AM SOC INF SCI TECHNOL, V59, P830 & 38 \\
\hline 72 & Chavalarias D, 2008, SCIENTOMETRICS, V75, P37 & 3 \\
\hline 73 & Li XY, 2008, INFORM PROCESS MANAGE, V44, P991 & 0 \\
\hline 74 & Wan XJ, 2008, INFORM PROCESS MANAGE, V44, P1032 & 3 \\
\hline 75 & Molinari A, 2008, SCIENTOMETRICS, V75, P339 & 7 \\
\hline 76 & Bettencourt LMA, 2008, SCIENTOMETRICS, V75, P495 & 7 \\
\hline 77 & Kim H, 2008, SCIENTOMETRICS, V75, P535 & 2 \\
\hline 78 & Harmon G, 2008, INFORM PROCESS MANAGE, V44, P1634 & 0 \\
\hline 79 & Bornmann L, 2008, J INFORMETR, V2, P217 & 2 \\
\hline 80 & Yu HR, 2008, J INFORMETR, V2, P240 & 0 \\
\hline 81 & Egghe L, 2008, SCIENTOMETRICS, V76, P117 & 4 \\
\hline 82 & Egghe L, 2008, J AM SOC INF SCI TECHNOL, V59, P1608 & 13 \\
\hline 83 & van Raan AFJ, 2008, J AM SOC INF SCI TECHNOL, V59, P1631 & 3 \\
\hline 84 & Egghe L, 2008, J AM SOC INF SCI TECHNOL, V59, P1688 & 2 \\
\hline 85 & Ahlgren P, 2008, SCIENTOMETRICS, V76, P273 & 3 \\
\hline 86 & Burrell QL, 2008, INFORM PROCESS MANAGE, V44, P1794 & 1 \\
\hline 87 & Bornmann L, 2008, J INFORMETR, V2, P280 & 0 \\
\hline 88 & Ye FY, 2008, J INFORMETR, V2, P288 & 2 \\
\hline 89 & Quirin A, 2008, J AM SOC INF SCI TECHNOL, V59, P1912 & 2 \\
\hline 90 & Lucio-Arias D, 2008, J AM SOC INF SCI TECHNOL, V59, P1948 & 3 \\
\hline 91 & Levitt JM, 2008, J AM SOC INF SCI TECHNOL, V59, P1973 & 3 \\
\hline 92 & Cecchini RL, 2008, INFORM PROCESS MANAGE, V44, P1863 & 1 \\
\hline 93 & Egghe L, 2008, J AM SOC INF SCI TECHNOL, V59, P2133 & 0 \\
\hline 94 & Davis PM, 2008, J AM SOC INF SCI TECHNOL, V59, P2186 & 6 \\
\hline 95 & Egghe L, 2008, SCIENTOMETRICS, V77, P377 & 3 \\
\hline 96 & Szydlowski M, 2009, SCIENTOMETRICS, V78, P99 & 0 \\
\hline 97 & Wallace ML, 2009, J AM SOC INF SCI TECHNOL, V60, P240 & 1 \\
\hline 98 & Jensen P, 2009, SCIENTOMETRICS, V78, P467 & 0 \\
\hline
\end{tabular}


Table 2.6 (continued)

\begin{tabular}{|c|c|c|}
\hline Node & Bibliographic metadata & Times cited \\
\hline 99 & Costas R, 2009, J AM SOC INF SCI TECHNOL, V60, P740 & 3 \\
\hline 100 & Perez JM, 2009, INFORM PROCESS MANAGE, V45, P356 & 0 \\
\hline 101 & Sandstrom U, 2009, SCIENTOMETRICS, V79, P341 & 1 \\
\hline 102 & Borner K, 2009, J INFORMETR, V3, P161 & 0 \\
\hline 103 & Chen CM, 2009, J INFORMETR, V3, P191 & 2 \\
\hline 104 & Bettencourt LMA, 2009, J INFORMETR, V3, P210 & 4 \\
\hline 105 & Frenken K, 2009, J INFORMETR, V3, P222 & 2 \\
\hline 106 & Skupin A, 2009, J INFORMETR, V3, P233 & 2 \\
\hline 107 & Lucio-Arias D, 2009, J INFORMETR, V3, P261 & 6 \\
\hline 108 & Zhao YY, 2009, SCIENTOMETRICS, V80, P91 & 0 \\
\hline 109 & Elmacioglu E, 2009, SCIENTOMETRICS, V80, P195 & 0 \\
\hline 110 & Zhu SF, 2009, INFORM PROCESS MANAGE, V45, P555 & 1 \\
\hline 111 & Deineko VG, 2009, SCIENTOMETRICS, V80, P819 & 0 \\
\hline 112 & Egghe L, 2009, J INFORMETR, V3, P290 & 2 \\
\hline 113 & Wallace ML, 2009, J INFORMETR, V3, P296 & 2 \\
\hline 114 & Yu LP, 2009, J INFORMETR, V3, P304 & 0 \\
\hline 115 & Kwakkel JH, 2009, J AM SOC INF SCI TECHNOL, V60, P2064 & 0 \\
\hline 116 & He ZL, 2009, J AM SOC INF SCI TECHNOL, V60, P2151 & 0 \\
\hline 117 & Tseng YH, 2009, SCIENTOMETRICS, V81, P73 & 1 \\
\hline 118 & Egghe L, 2009, J AM SOC INF SCI TECHNOL, V60, P2362 & 1 \\
\hline 119 & Bornmann L, 2009, SCIENTOMETRICS, V81, P407 & 1 \\
\hline 120 & Ye FY, 2009, SCIENTOMETRICS, V81, P493 & 0 \\
\hline 121 & Egghe L, 2009, SCIENTOMETRICS, V81, P567 & 0 \\
\hline 122 & Lucio-Arias D, 2009, J AM SOC INF SCI TECHNOL, V60, P2488 & 0 \\
\hline 123 & Luk R, 2009, J AM SOC INF SCI TECHNOL, V60, P2587 & 0 \\
\hline 124 & Guan JC, 2009, SCIENTOMETRICS, V81, P683 & 0 \\
\hline 125 & Kiss IZ, 2010, J INFORMETR, V4, P74 & 0 \\
\hline 126 & Bornmann L, 2010, J INFORMETR, V4, P83 & 1 \\
\hline 127 & Guan JC, 2010, SCIENTOMETRICS, V82, P165 & 0 \\
\hline 128 & Egghe L, 2010, SCIENTOMETRICS, V82, P243 & 0 \\
\hline 129 & Yu G, 2010, SCIENTOMETRICS, V82, P249 & 0 \\
\hline 130 & Xu ZB, 2010, INFORM PROCESS MANAGE, V46, P143 & 0 \\
\hline 131 & Pepe A, 2010, J AM SOC INF SCI TECHNOL, V61, P567 & 0 \\
\hline 132 & Liang LM, 2010, J INFORMETR, V4, P201 & 0 \\
\hline 133 & Minguillo D, 2010, J AM SOC INF SCI TECHNOL, V61, P772 & 0 \\
\hline 134 & Zhang HZ, 2010, J AM SOC INF SCI TECHNOL, V61, P964 & 0 \\
\hline 135 & Egghe L, 2010, SCIENTOMETRICS, V83, P455 & 0 \\
\hline 136 & Wray KB, 2010, SCIENTOMETRICS, V83, P471 & 0 \\
\hline 137 & Schiebel E, 2010, SCIENTOMETRICS, V83, P765 & 0 \\
\hline
\end{tabular}




\section{Appendix 2: Cognitive Historiography of Papers Using Mathematical Approaches to Understand the Science System} (Fig. 2.2)

Table 2.7 Statistics of the search: Present to past

\begin{tabular}{|c|c|c|}
\hline Node & Bibliographic metadata & Times cited \\
\hline 1 & Lotka AJ, 1926, J WASHINGTON ACADEMY, V16, P317 & 317 \\
\hline 2 & PRICE DJD, 1965, SCIENCE, V149, P510 & 664 \\
\hline 3 & PRICE DJD, 1976, J AMER SOC INFORM SCI, V27, P292 & 332 \\
\hline 4 & Barabási AL, 1999, SCIENCE, V286, P509 & 4818 \\
\hline 5 & Albert R, 2002, REV MOD PHYS, V74, P47 & 4030 \\
\hline 6 & Torvik VI, 2005, J AM SOC INF SCI TECHNOL, V56, P140 & 18 \\
\hline 7 & Xekalaki E, 2005, SCIENTOMETRICS, V62, P293 & 1 \\
\hline 8 & Santos JB, 2005, SCIENTOMETRICS, V62, P329 & 2 \\
\hline 9 & Simkin MV, 2005, SCIENTOMETRICS, V62, P367 & 8 \\
\hline 10 & Bailon-Moreno R, 2005, SCIENTOMETRICS, V63, P231 & 1 \\
\hline 11 & Egghe L, 2005, J AM SOC INF SCI TECHNOL, V56, P664 & 2 \\
\hline 12 & Egghe L, 2005, J AM SOC INF SCI TECHNOL, V56, P669 & 8 \\
\hline 13 & Sombatsompop N, 2005, J AM SOC INF SCI TECHNOL, V56, P676 & 15 \\
\hline 14 & Matia K, 2005, J AM SOC INF SCI TECHNOL, V56, P893 & 10 \\
\hline 15 & Egghe L, 2005, J AM SOC INF SCI TECHNOL, V56, P935 & 13 \\
\hline 16 & Efron M, 2005, J AM SOC INF SCI TECHNOL, V56, P969 & 4 \\
\hline 17 & Liang LM, 2005, J AM SOC INF SCI TECHNOL, V56, P1045 & 10 \\
\hline 18 & Burrell QL, 2005, SCIENTOMETRICS, V64, P247 & 5 \\
\hline 19 & Morris SA, 2005, J AM SOC INF SCI TECHNOL, V56, P1250 & 5 \\
\hline 20 & Hirsch JE, 2005, PROC NAT ACAD SCI USA, V102, P16569 & 549 \\
\hline 21 & Burrell QL, 2005, INFORM PROCESS MANAGE, V41, P1317 & 8 \\
\hline 22 & Egghe L, 2005, INFORM PROCESS MANAGE, V41, P1330 & 2 \\
\hline 23 & Shan S, 2005, INFORM PROCESS MANAGE, V41, P1369 & 2 \\
\hline 24 & Lafouge T, 2005, INFORM PROCESS MANAGE, V41, P1387 & 3 \\
\hline 25 & Payne N, 2005, INFORM PROCESS MANAGE, V41, P1495 & 1 \\
\hline 26 & Coccia M, 2005, SCIENTOMETRICS, V65, P307 & 0 \\
\hline 27 & Burrell QL, 2005, SCIENTOMETRICS, V65, P381 & 11 \\
\hline 28 & Bornmann L, 2005, SCIENTOMETRICS, V65, P391 & 86 \\
\hline 29 & Dominich S, 2006, INFORM PROCESS MANAGE, V42, P1 & 0 \\
\hline 30 & Zuccala A, 2006, J AM SOC INF SCI TECHNOL, V57, P152 & 14 \\
\hline 31 & Aksnes DW, 2006, J AM SOC INF SCI TECHNOL, V57, P169 & 13 \\
\hline 32 & Klavans R, 2006, J AM SOC INF SCI TECHNOL, V57, P251 & 33 \\
\hline 33 & Ackermann E, 2006, SCIENTOMETRICS, V66, P451 & 0 \\
\hline 34 & Martens BVD, 2006, J AM SOC INF SCI TECHNOL, V57, P330 & 1 \\
\hline 35 & Chen CM, 2006, J AM SOC INF SCI TECHNOL, V57, P359 & 67 \\
\hline 36 & van Raan AFJ, 2006, J AM SOC INF SCI TECHNOL, V57, P408 & 21 \\
\hline 37 & Choi J, 2006, INFORM PROCESS MANAGE, V42, P331 & 5 \\
\hline 38 & Wei CP, 2006, INFORM PROCESS MANAGE, V42, P350 & 12 \\
\hline 39 & Izsak J, 2006, SCIENTOMETRICS, V67, P107 & 2 \\
\hline 40 & Yoo SH, 2006, SCIENTOMETRICS, V69, P57 & 0 \\
\hline
\end{tabular}


Table 2.7 (continued)

\begin{tabular}{|c|c|c|}
\hline Node & Bibliographic metadata & Times cited \\
\hline$\overline{41}$ & Egghe L, 2006, SCIENTOMETRICS, V69, P121 & 67 \\
\hline 42 & Glanzel W, 2006, SCIENTOMETRICS, V67, P315 & 73 \\
\hline 43 & Burrell QL, 2006, SCIENTOMETRICS, V67, P323 & 0 \\
\hline 44 & Rousseau R, 2006, J AM SOC INF SCI TECHNOL, V57, P1404 & 2 \\
\hline 45 & Burrell QL, 2006, J AM SOC INF SCI TECHNOL, V57, P1406 & 4 \\
\hline 46 & Samoylenko I, 2006, J AM SOC INF SCI TECHNOL, V57, P1461 & 7 \\
\hline 47 & Peng D, 2006, SCIENTOMETRICS, V69, P271 & 0 \\
\hline 48 & Roth C, 2006, SCIENTOMETRICS, V69, P429 & 5 \\
\hline 49 & Mingers J, 2006, INFORM PROCESS MANAGE, V42, P1451 & 6 \\
\hline 50 & Zitt M, 2006, INFORM PROCESS MANAGE, V42, P1513 & 17 \\
\hline 51 & Su Y, 2006, J AM SOC INF SCI TECHNOL, V57, P1977 & 0 \\
\hline 52 & Van Den Besselaar P, 2006, SCIENTOMETRICS, V68, P377 & 10 \\
\hline 53 & Borner K, 2006, SCIENTOMETRICS, V68, P415 & 8 \\
\hline 54 & Klavans R, 2006, SCIENTOMETRICS, V68, P475 & 15 \\
\hline 55 & Small H, 2006, SCIENTOMETRICS, V68, P595 & 23 \\
\hline 56 & Contreras C, 2006, SCIENTOMETRICS, V69, P689 & 3 \\
\hline 57 & Kretschmer H, 2007, J INFORMETR, V1, P308 & 1 \\
\hline 58 & Jarneving B, 2007, J INFORMETR, V1, P338 & 0 \\
\hline 59 & Burrell QL, 2007, J INFORMETR, V1, P16 & 22 \\
\hline 60 & Leydesdorff L, 2007, J AM SOC INF SCI TECHNOL, V58, P25 & 14 \\
\hline 61 & McDonald JD, 2007, J AM SOC INF SCI TECHNOL, V58, P39 & 4 \\
\hline 62 & Koike A, 2007, J AM SOC INF SCI TECHNOL, V58, P51 & 2 \\
\hline 63 & Egghe L, 2007, J AM SOC INF SCI TECHNOL, V58, P452 & 29 \\
\hline 64 & Na SH, 2007, INFORM PROCESS MANAGE, V43, P302 & 1 \\
\hline 65 & Lucio-Arias D, 2007, SCIENTOMETRICS, V70, P603 & 3 \\
\hline 66 & Egghe L, 2007, J INFORMETR, V1, P115 & 5 \\
\hline 67 & Shibata N, 2007, J AM SOC INF SCI TECHNOL, V58, P872 & 2 \\
\hline 68 & Zitt M, 2007, INFORM PROCESS MANAGE, V43, P834 & 0 \\
\hline 69 & Zhao DZ, 2007, J AM SOC INF SCI TECHNOL, V58, P1285 & 2 \\
\hline 70 & Rousseau R, 2007, J AM SOC INF SCI TECHNOL, V58, P1551 & 3 \\
\hline 71 & Nadarajah S, 2007, SCIENTOMETRICS, V72, P291 & 1 \\
\hline 72 & Simkin MV, 2007, J AM SOC INF SCI TECHNOL, V58, P1661 & 6 \\
\hline 73 & Morris SA, 2007, J AM SOC INF SCI TECHNOL, V58, P1764 & 4 \\
\hline 74 & Bornmann L, 2007, SCIENTOMETRICS, V73, P139 & 1 \\
\hline 75 & de Moya-Anegon F, 2007, J AM SOC INF SCI TECHNOL, V58, P2167 & 9 \\
\hline 76 & Lariviere V, 2008, J AM SOC INF SCI TECHNOL, V59, P288 & 12 \\
\hline 77 & van Raan AFJ, 2008, J AM SOC INF SCI TECHNOL, V59, P565 & 7 \\
\hline 78 & Bornmann L, 2008, J AM SOC INF SCI TECHNOL, V59, P830 & 38 \\
\hline 79 & Chavalarias D, 2008, SCIENTOMETRICS, V75, P37 & 3 \\
\hline 80 & Li XY, 2008, INFORM PROCESS MANAGE, V44, P991 & 0 \\
\hline 81 & Wan XJ, 2008, INFORM PROCESS MANAGE, V44, P1032 & 3 \\
\hline 82 & Molinari A, 2008, SCIENTOMETRICS, V75, P339 & 7 \\
\hline 83 & Bettencourt LMA, 2008, SCIENTOMETRICS, V75, P495 & 7 \\
\hline 84 & Kim H, 2008, SCIENTOMETRICS, V75, P535 & 2 \\
\hline 85 & Harmon G, 2008, INFORM PROCESS MANAGE, V44, P1634 & 0 \\
\hline 86 & Bornmann L, 2008, J INFORMETR, V2, P217 & 2 \\
\hline
\end{tabular}


Table 2.7 (continued)

\begin{tabular}{|c|c|c|}
\hline Node & Bibliographic metadata & Times cited \\
\hline 87 & Yu HR, 2008, J INFORMETR, V2, P240 & 0 \\
\hline 88 & Egghe L, 2008, SCIENTOMETRICS, V76, P117 & 4 \\
\hline 89 & Egghe L, 2008, J AM SOC INF SCI TECHNOL, V59, P1608 & 13 \\
\hline 90 & van Raan AFJ, 2008, J AM SOC INF SCI TECHNOL, V59, P1631 & 3 \\
\hline 91 & Egghe L, 2008, J AM SOC INF SCI TECHNOL, V59, P1688 & 2 \\
\hline 92 & Ahlgren P, 2008, SCIENTOMETRICS, V76, P273 & 3 \\
\hline 93 & Burrell QL, 2008, INFORM PROCESS MANAGE, V44, P1794 & 1 \\
\hline 94 & Bornmann L, 2008, J INFORMETR, V2, P280 & 0 \\
\hline 95 & Ye FY, 2008, J INFORMETR, V2, P288 & 2 \\
\hline 96 & Quirin A, 2008, J AM SOC INF SCI TECHNOL, V59, P1912 & 2 \\
\hline 97 & Lucio-Arias D, 2008, J AM SOC INF SCI TECHNOL, V59, P1948 & 3 \\
\hline 98 & Levitt JM, 2008, J AM SOC INF SCI TECHNOL, V59, P1973 & 3 \\
\hline 99 & Cecchini RL, 2008, INFORM PROCESS MANAGE, V44, P1863 & 1 \\
\hline 100 & Egghe L, 2008, J AM SOC INF SCI TECHNOL, V59, P2133 & 0 \\
\hline 101 & Davis PM, 2008, J AM SOC INF SCI TECHNOL, V59, P2186 & 6 \\
\hline 102 & Egghe L, 2008, SCIENTOMETRICS, V77, P377 & 3 \\
\hline 103 & Szydlowski M, 2009, SCIENTOMETRICS, V78, P99 & 0 \\
\hline 104 & Wallace ML, 2009, J AM SOC INF SCI TECHNOL, V60, P240 & 1 \\
\hline 105 & Jensen P, 2009, SCIENTOMETRICS, V78, P467 & 0 \\
\hline 106 & Costas R, 2009, J AM SOC INF SCI TECHNOL, V60, P740 & 3 \\
\hline 107 & Perez JM, 2009, INFORM PROCESS MANAGE, V45, P356 & 0 \\
\hline 108 & Sandstrom U, 2009, SCIENTOMETRICS, V79, P341 & 1 \\
\hline 109 & Borner K, 2009, J INFORMETR, V3, P161 & 0 \\
\hline 110 & Chen CM, 2009, J INFORMETR, V3, P191 & 2 \\
\hline 111 & Bettencourt LMA, 2009, J INFORMETR, V3, P210 & 4 \\
\hline 112 & Frenken K, 2009, J INFORMETR, V3, P222 & 2 \\
\hline 113 & Skupin A, 2009, J INFORMETR, V3, P233 & 2 \\
\hline 114 & Lucio-Arias D, 2009, J INFORMETR, V3, P261 & 6 \\
\hline 115 & Zhao YY, 2009, SCIENTOMETRICS, V80, P91 & 0 \\
\hline 116 & Elmacioglu E, 2009, SCIENTOMETRICS, V80, P195 & 0 \\
\hline 117 & Zhu SF, 2009, INFORM PROCESS MANAGE, V45, P555 & 1 \\
\hline 118 & Deineko VG, 2009, SCIENTOMETRICS, V80, P819 & 0 \\
\hline 119 & Egghe L, 2009, J INFORMETR, V3, P290 & 2 \\
\hline 120 & Wallace ML, 2009, J INFORMETR, V3, P296 & 2 \\
\hline 121 & Yu LP, 2009, J INFORMETR, V3, P304 & 0 \\
\hline 122 & Kwakkel JH, 2009, J AM SOC INF SCI TECHNOL, V60, P2064 & 0 \\
\hline 123 & He ZL, 2009, J AM SOC INF SCI TECHNOL, V60, P2151 & 0 \\
\hline 124 & Tseng YH, 2009, SCIENTOMETRICS, V81, P73 & 1 \\
\hline 125 & Egghe L, 2009, J AM SOC INF SCI TECHNOL, V60, P2362 & 1 \\
\hline 126 & Bornmann L, 2009, SCIENTOMETRICS, V81, P407 & 1 \\
\hline 127 & Ye FY, 2009, SCIENTOMETRICS, V81, P493 & 0 \\
\hline 128 & Egghe L, 2009, SCIENTOMETRICS, V81, P567 & 0 \\
\hline 129 & Lucio-Arias D, 2009, J AM SOC INF SCI TECHNOL, V60, P2488 & 0 \\
\hline 130 & Luk R, 2009, J AM SOC INF SCI TECHNOL, V60, P2587 & 0 \\
\hline 131 & Guan JC, 2009, SCIENTOMETRICS, V81, P683 & 0 \\
\hline 132 & Kiss IZ, 2010, J INFORMETR, V4, P74 & 0 \\
\hline
\end{tabular}


Table 2.7 (continued)

\begin{tabular}{lll}
\hline Node & Bibliographic metadata & Times cited \\
\hline 133 & Bornmann L, 2010, J INFORMETR, V4, P83 & 1 \\
134 & Guan JC, 2010, SCIENTOMETRICS, V82, P165 & 0 \\
135 & Egghe L, 2010, SCIENTOMETRICS, V82, P243 & 0 \\
136 & Yu G, 2010, SCIENTOMETRICS, V82, P249 & 0 \\
137 & Xu ZB, 2010, INFORM PROCESS MANAGE, V46, P143 & 0 \\
138 & Pepe A, 2010, J AM SOC INF SCI TECHNOL, V61, P567 & 0 \\
139 & Liang LM, 2010, J INFORMETR, V4, P201 & 0 \\
140 & Minguillo D, 2010, J AM SOC INF SCI TECHNOL, V61, P772 & 0 \\
141 & Zhang HZ, 2010, J AM SOC INF SCI TECHNOL, V61, P964 & 0 \\
142 & Egghe L, 2010, SCIENTOMETRICS, V83, P455 & 0 \\
143 & Wray KB, 2010, SCIENTOMETRICS, V83, P471 & 0 \\
144 & Schiebel E, 2010, SCIENTOMETRICS, V83, P765 & 0 \\
\hline
\end{tabular}

\section{Appendix 3: Papers from Threads in Figs. 2.3-2.6}

Table 2.8 Documents in Fig. 2.3

\begin{tabular}{|c|c|c|c|c|}
\hline Node & Author & Year & Journal & Title \\
\hline 4 & Simkin, MV & 2005 & SCIENTOMETRICS & $\begin{array}{l}\text { Stochastic modeling of citation } \\
\text { slips }\end{array}$ \\
\hline 10 & Egghe, L & 2005 & JASIST & $\begin{array}{l}\text { Zipfian and Lotkaian continuous } \\
\text { concentration theory }\end{array}$ \\
\hline 12 & Liang, LM & 2005 & JASIST & $\begin{array}{l}\text { R-sequences: Relative indicators } \\
\text { for the rhythm of science }\end{array}$ \\
\hline 15 & Burrell, QL & 2005 & $\begin{array}{l}\text { INFORMATION } \\
\text { PROCESSING \& } \\
\text { MANAGEMENT }\end{array}$ & $\begin{array}{l}\text { Symmetry and other } \\
\text { transformation features of } \\
\text { Lorenz/Leimkuhler } \\
\text { representations of informetric } \\
\text { data }\end{array}$ \\
\hline 21 & Burrell, QL & 2005 & SCIENTOMETRICS & $\begin{array}{l}\text { Are "sleeping beauties" to be } \\
\text { expected? }\end{array}$ \\
\hline 29 & van Raan, AFJ & 2006 & JASIST & $\begin{array}{l}\text { Statistical properties of } \\
\text { Bibliometric indicators: } \\
\text { Research group indicator } \\
\text { distributions and correlations }\end{array}$ \\
\hline 38 & Burrell, QL & 2006 & JASIST & $\begin{array}{l}\text { On Egghe's version of continuous } \\
\text { concentration theory }\end{array}$ \\
\hline 42 & Mingers, J & 2006 & $\begin{array}{l}\text { INFORMATION } \\
\text { PROCESSING \& } \\
\text { MANAGEMENT }\end{array}$ & $\begin{array}{l}\text { Modeling citation behavior in } \\
\text { Management Science journals }\end{array}$ \\
\hline
\end{tabular}


Table 2.8 (continued)

\begin{tabular}{|c|c|c|c|c|}
\hline Node & Author & Year & Journal & Title \\
\hline 63 & Rousseau, R & 2007 & JASIST & $\begin{array}{l}\text { On Egghe's construction of } \\
\text { Lorenz curves }\end{array}$ \\
\hline 64 & Nadarajah, S & 2007 & SCIENTOMETRICS & Models for citation behavior \\
\hline 65 & Simkin, MV & 2007 & JASIST & A mathematical theory of citing \\
\hline 69 & Lariviere, $\mathrm{V}$ & 2008 & JASIST & $\begin{array}{l}\text { Long-term variations in the aging } \\
\text { of scientific literature: From } \\
\text { exponential growth to } \\
\text { steady-state science } \\
(1900-2004)\end{array}$ \\
\hline 70 & van Raan, AFJ & 2008 & JASIST & $\begin{array}{l}\text { Self-citation as an } \\
\text { impact-reinforcing mechanism } \\
\text { in the science system }\end{array}$ \\
\hline 83 & van Raan, AFJ & 2008 & JASIST & $\begin{array}{l}\text { Scaling rules in the science } \\
\text { system: Influence of } \\
\text { field-specific citation } \\
\text { characteristics on the impact } \\
\text { of research groups }\end{array}$ \\
\hline
\end{tabular}

Table 2.9 Documents in Fig. 2.4

\begin{tabular}{|c|c|c|c|c|}
\hline Node & Author & Year & Journal & Title \\
\hline 25 & Klavans, $\mathrm{R}$ & 2006 & JASIST & $\begin{array}{l}\text { Identifying a better measure } \\
\text { of relatedness for } \\
\text { mapping science }\end{array}$ \\
\hline 28 & Chen, CM & 2006 & JASIST & $\begin{array}{l}\text { CiteSpace II: Detecting and } \\
\text { visualizing emerging } \\
\text { trends and transient } \\
\text { patterns in scientific } \\
\text { literature }\end{array}$ \\
\hline 45 & $\begin{array}{l}\text { Van Den } \\
\quad \text { Besselaar, P }\end{array}$ & 2006 & SCIENTOMETRICS & $\begin{array}{l}\text { Mapping research topics } \\
\text { using word-reference } \\
\text { co-occurrences: A } \\
\text { method and an } \\
\text { exploratory case study }\end{array}$ \\
\hline 46 & Borner, K & 2006 & SCIENTOMETRICS & $\begin{array}{l}\text { Mapping the diffusion of } \\
\text { scholarly knowledge } \\
\text { among major US } \\
\text { research institutions }\end{array}$ \\
\hline 47 & Klavans, $\mathrm{R}$ & 2006 & SCIENTOMETRICS & $\begin{array}{l}\text { Quantitative evaluation of } \\
\text { large maps of science }\end{array}$ \\
\hline 48 & Small, H & 2006 & SCIENTOMETRICS & $\begin{array}{l}\text { Tracking and predicting } \\
\text { growth areas in science }\end{array}$ \\
\hline 58 & Lucio-Arias, D & 2007 & SCIENTOMETRICS & $\begin{array}{l}\text { Knowledge emergence in } \\
\text { scientific } \\
\text { communication: from } \\
\text { "fullerenes" to } \\
\text { "nanotubes" }\end{array}$ \\
\hline
\end{tabular}


Table 2.9 (continued)

\begin{tabular}{|c|c|c|c|c|}
\hline Node & Author & Year & Journal & Title \\
\hline 60 & Shibata, N & 2007 & JASIST & $\begin{array}{l}\text { Topological analysis of citation } \\
\text { networks to discover the } \\
\text { future core articles }\end{array}$ \\
\hline 67 & Bornmann, L & 2007 & SCIENTOMETRICS & $\begin{array}{l}\text { Row-column }(\mathrm{RC}) \text { association } \\
\text { model applied to grant peer } \\
\text { review }\end{array}$ \\
\hline 72 & Chavalarias, D & 2008 & SCIENTOMETRICS & $\begin{array}{l}\text { Bottom-up scientific field } \\
\text { detection for dynamical and } \\
\text { hierarchical science mapping, } \\
\text { methodology and case study }\end{array}$ \\
\hline 76 & Bettencourt, LMA & 2008 & SCIENTOMETRICS & $\begin{array}{l}\text { Population modeling of the } \\
\text { emergence and development } \\
\text { of scientific fields }\end{array}$ \\
\hline 79 & Bornmann, L & 2008 & $\begin{array}{l}\text { JOURNAL OF } \\
\text { INFORMETRICS }\end{array}$ & $\begin{array}{l}\text { Latent Markov modeling applied } \\
\text { to grant peer review }\end{array}$ \\
\hline 90 & Lucio-Arias, D & 2008 & JASIST & $\begin{array}{l}\text { Main-path analysis and } \\
\text { path-dependent transitions in } \\
\text { HistCite (TM)-based } \\
\text { historiograms }\end{array}$ \\
\hline 102 & Borner, K & 2009 & $\begin{array}{l}\text { JOURNAL OF } \\
\text { INFORMETRICS }\end{array}$ & $\begin{array}{l}\text { Visual conceptualizations and } \\
\text { models of science }\end{array}$ \\
\hline 103 & Chen, CM & 2009 & $\begin{array}{l}\text { JOURNAL OF } \\
\text { INFORMETRICS }\end{array}$ & $\begin{array}{l}\text { Towards an explanatory and } \\
\text { computational theory of } \\
\text { scientific discovery }\end{array}$ \\
\hline 104 & Bettencourt, LMA & 2009 & $\begin{array}{l}\text { JOURNAL OF } \\
\text { INFORMETRICS }\end{array}$ & $\begin{array}{l}\text { Scientific discovery and } \\
\text { topological transitions in } \\
\text { collaboration networks }\end{array}$ \\
\hline 105 & Frenken, $\mathrm{K}$ & 2009 & $\begin{array}{l}\text { JOURNAL OF } \\
\text { INFORMETRICS }\end{array}$ & $\begin{array}{l}\text { Spatial scientometrics: Towards a } \\
\text { cumulative research program }\end{array}$ \\
\hline 106 & Skupin, A & 2009 & $\begin{array}{l}\text { JOURNAL OF } \\
\text { INFORMETRICS }\end{array}$ & $\begin{array}{l}\text { Discrete and continuous } \\
\text { conceptualizations of science: } \\
\text { Implications for knowledge } \\
\text { domain visualization }\end{array}$ \\
\hline 107 & Lucio-Arias, D & 2009 & $\begin{array}{l}\text { JOURNAL OF } \\
\text { INFORMETRICS }\end{array}$ & $\begin{array}{l}\text { The dynamics of exchanges and } \\
\text { references among scientific } \\
\text { texts, and the autopoiesis of } \\
\text { discursive knowledge }\end{array}$ \\
\hline
\end{tabular}

Table 2.10 Documents in Fig. 2.5

\begin{tabular}{lllll}
\hline Node & Author & Year & Journal & Title \\
\hline 2 & Xekalaki, E & 2005 & SCIENTOMETRICS & $\begin{array}{c}\text { Comments on the paper of Shan } \\
\text { et al.: The multivariate } \\
\text { Waring distribution }\end{array}$ \\
& Egghe, L & 2005 & JASIST & $\begin{array}{l}\text { The power of power laws and an } \\
\text { interpretation of Lotkaian } \\
\text { informetric systems as } \\
\text { self-similar fractals }\end{array}$ \\
& & & & \\
& & &
\end{tabular}


Table 2.10 (continued)

\begin{tabular}{|c|c|c|c|c|}
\hline Node & Author & Year & Journal & Title \\
\hline 13 & Burrell, QL & 2005 & SCIENTOMETRICS & $\begin{array}{l}\text { The use of the generalized } \\
\text { Waring process in modelling } \\
\text { informetric data }\end{array}$ \\
\hline 34 & Egghe, L & 2006 & SCIENTOMETRICS & $\begin{array}{l}\text { An informetric model for the } \\
\text { Hirsch-index }\end{array}$ \\
\hline 35 & Glanzel, W & 2006 & SCIENTOMETRICS & $\begin{array}{l}\text { On the h-index - A mathematical } \\
\text { approach to a new measure of } \\
\text { publication activity and } \\
\text { citation impact }\end{array}$ \\
\hline 43 & Zitt, M & 2006 & $\begin{array}{l}\text { INFORMATION } \\
\text { PROCESSING \& } \\
\text { MANAGEMENT }\end{array}$ & $\begin{array}{l}\text { Delineating complex scientific } \\
\text { fields by an hybrid } \\
\text { lexical-citation method: An } \\
\text { application to nanosciences }\end{array}$ \\
\hline 52 & Burrell, QL & 2007 & $\begin{array}{l}\text { JOURNAL OF } \\
\text { INFORMETRICS }\end{array}$ & $\begin{array}{l}\text { Hirsch's h-index: A stochastic } \\
\text { model }\end{array}$ \\
\hline 56 & Egghe, L & 2007 & JASIST & $\begin{array}{l}\text { Dynamic h-index: The Hirsch } \\
\text { index in function of time }\end{array}$ \\
\hline 81 & Egghe, L & 2008 & JASIST & $\begin{array}{l}\text { A Model for the Size-Frequency } \\
\text { Function of Coauthor Pairs }\end{array}$ \\
\hline 95 & Egghe, L & 2008 & SCIENTOMETRICS & $\begin{array}{l}\text { The mathematical relation } \\
\text { between the impact factor } \\
\text { and the uncitedness factor }\end{array}$ \\
\hline
\end{tabular}

Table 2.11 Documents in Fig. 2.3

\begin{tabular}{|c|c|c|c|c|}
\hline Node & Author & Year & Journal & Title \\
\hline 14 & Morris, SA & 2005 & JASIST & $\begin{array}{l}\text { Manifestation of emerging } \\
\text { specialties in journal literature: } \\
\text { A growth model of papers, } \\
\text { references, exemplars, } \\
\text { bibliographic coupling, } \\
\text { cocitation, and clustering } \\
\text { coefficient distribution }\end{array}$ \\
\hline 39 & Samoylenko, I & 2006 & JASIST & $\begin{array}{l}\text { Visualizing the scientific world and } \\
\text { its evolution }\end{array}$ \\
\hline 50 & Kretschmer, $\mathrm{H}$ & 2007 & $\begin{array}{l}\text { JOURNAL OF } \\
\text { INFORMETRICS }\end{array}$ & $\begin{array}{l}\text { Lotka's distribution and distribution } \\
\text { of co-author pairs' frequencies }\end{array}$ \\
\hline 53 & Leydesdorff, L & 2007 & JASIST & $\begin{array}{l}\text { Visualization of the citation impact } \\
\text { environments of scientific } \\
\text { journals: An online mapping } \\
\text { exercise }\end{array}$ \\
\hline 66 & Morris, SA & 2007 & JASIST & $\begin{array}{l}\text { Manifestation of research teams in } \\
\text { journal literature: A growth } \\
\text { model of papers, coauthorship, } \\
\text { weak ties, authors, } \\
\text { collaboration, and Lotka's law }\end{array}$ \\
\hline 68 & $\begin{array}{l}\text { de Moya- } \\
\text { Anegon, F }\end{array}$ & 2007 & JASIST & Visualizing the marrow of science \\
\hline
\end{tabular}




\section{References}

Albert R, Barabasi AL (2002) Statistical mechanics of complex networks. Rev. Mod. Phys 74:47-97

Bak P (1996) How nature works: The science of self-organized criticality. Copernicus, New York, NY

Barabasi AL, Albert R (1999) Emergence of scaling in random networks. Science 286:509-512

Barabási AL (2002) Linked: The new science of networks. Perseus Publishing, Cambridge, MA

Batagelj V (2003) Efficient algorithms for citation network analysis. Arxiv preprint arXiv:cs/0309023

Bettencourt LMA, Kaiser DI, Kaur J (2009) Scientific discovery and topological transitions in collaboration networks. J Informetr 3(3):210-221 (DOI: 10.1016/j.joi.2009.03.001)

Börner K, Sanyal S, Vespignani A (2007) Network science. Ann Rev Inf Sci Technol 41:537-607 (DOI: 10.1002/aris.2007.1440410119)

Boyack KW, Klavans R (2009) The fabric of science. Presentation given at the workshop 'Modelling science dynamics', Amsterdam, 2009, also see the URL: http://scimaps.org/maps/map/ weaving_the_fabric_o_119

Bruckner E, Ebeling W, Scharnhorst A (1990) The application of evolution models in scientometrics. Scientometrics 18(1):21-41 (DOI: 10.1007/BF02019160)

Burger M, Bujdoso E (1985) Oscillating chemical reactions as an example of the development of a subfield of science. In: Field RJ, Burger M (eds) Oscillations and traveling waves in chemical systems. Wiley, New York, NY, pp 565-604

Carley KM, Hummon NP, Harty M (1993) Scientific influence: An analysis of the main path structure in the Journal of Conflict Resolution. J Conflict Resolut 14(4):417-447 (DOI: $10.1177 / 107554709301400406)$

Chen C (2006) CiteSpace II: Detecting and visualizing emerging trends and transient patterns in scientific literature. J Am Soc Inf Sci Technol 57(3):359-377 (DOI: 10.1002/asi.20317)

Cronin B (1984) The citation process: The role and significance of citations in scientific communication. Taylor Graham, London

De Bellis N (2009) Bibliometrics and citation analysis: From the Science Citation Index to cybermetrics. Scarecrow, Lanham, MD

Domínguez Reboiras F, Villalba Varneda P, Walter P (eds) (2002) Arbor scientiae: Der Baum des Wissens von Ramon Lull. Akten des Internationalen Kongresses aus Anlaß des 40jährigen Jubiläums des RAIMUNDUS-LULLUS-INSTITUTS der Universität Freiburg i. Br.. Instrumenta Patristica et Mediaevalia - Research on the Inheritance of Early and Medieval Christianity, vol 42, Subsidia Lulliana, vol 1. Brepols Publishers, Turnhout

Ebeling W, Scharnhorst A (2009) Selbstorganisation und Mobilität von Wissenschaftlern Modelle für die Dynamik von Problemfeldern und Wissenschaftsgebieten. In: Ebeling W, Parthey H (eds) Selbstorganisation in Wissenschaft und Technik: Wissenschaftsforschung Jahrbuch 2008. Wissenschaftlicher Verlag Berlin, Berlin, pp 9-27, available online at the URL: http://www.wissenschaftsforschung.de/pbuch2008.html

Egghe L (2005) Power laws in the information production process: Lotkaian informetrics. Library and Information Science, vol 5. Elsevier, Amsterdam, available online at the URL: http://www.emeraldinsight.com/books.htm?issn=1876-0562\&volume=05

Egghe L, Rousseau R (1990) Introduction to informetrics: Quantitative methods in library, documentation and information science. Elsevier, Amsterdam

Epstein JM, Axtell R (1996) Growing artificial societies: Social science from the bottom up. Complex Adaptive Systems. Brookings Institution Press, Washington, DC; MIT Press, Cambridge, MA

Fronczak P, Fronczak A, Hołyst JA (2007) Publish or perish: Analysis of scientific productivity using maximum entropy principle and fluctuation-dissipation theorem. Phys Rev E 75(2):026103, p 9 (DOI: 10.1103/PhysRevE.75.026103), also available as arXiv preprint arXiv:physics/0606190 
Garfield E (1979) Citation indexing: Its theory and application in science, technology, and humanities. Information Sciences Series. Wiley, New York, NY

Garfield E, Sher IH, Torpie RJ (1964) The use of citation data in writing the history of science. Technical report, Institute for Scientific Information Inc. Philadelphia, PA. Report of research for the Air Force Office of Scientific Research under contract AF49 (638)-1256, also available online at the URL: http://www.garfield.library.upenn.edu/papers/useofcitdatawritinghistofs ci.pdf

Garfield E, Pudovkin AI, Istomin VS (2003a) Mapping the output of topical searches in the Web of Knowledge and the case of Watson-Crick. Inf Technol Libr 22(4):183-188, available online at the URL: http://www.garfield.library.upenn.edu/papers/casewatsoncrick2003.pdf

Garfield E, Pudovkin AI, Istomin VS (2003b) Why do we need Algorithmic Historiography? J Am Soc Inf Sci Technol 54(5):400-412 (DOI: 10.1002/asi.10226), also available online at the URL: http://www.garfield.library.upenn.edu/papers/jasist54(5)400y2003.pdf

Garfield E, Pudovkin AI, Istomin VS (2002) Algorithmic citation-linked histography mapping the literature of science. Proc Am Soc Inf Sci Technol 39:14-24 (DOI: 10.1002/meet.1450390102), also available online at the URL: http://www.garfield.library. upenn.edu/papers/asist2002proc.pdf

Gilbert GN, Mulkay MJ (1984) Opening Pandora's box: A sociological analysis of scientists' discourse. Cambridge University Press, Cambridge

Gilbert GN, Troitzsch KG (2005) Simulation for the social scientist, 2nd edn. Open University Press, Maidenhead

Gilbert N (1997) A simulation of the structure of academic science. Sociol Res Online 2(2), available online at the URL: http://www.socresonline.org.uk/2/2/3.html

Glänzel W, Schubert A (1995) Predictive aspects of a stochastic model for citation processes. Inf Process Manag 31(1):69-80 (DOI: 10.1016/0306-4573(95)80007-G)

Goffman W (1966) Mathematical approach to the spread of scientific ideas - the history of mast cell research. Nature 212(5061):449-452 (DOI: 10.1038/212449a0)

Goffman W, Newill VA (1964) Generalization of epidemic theory: An application to the transmission of ideas. Nature 204(4955):225-228 (DOI: 10.1038/204225a0)

Harmon G (2008) Remembering William Goffman: Mathematical information science pioneer. Inf Process Manag 44(4):1634-1647 (DOI: 10.1016/j.ipm.2007.12.004)

Havemann F (2009) Einführung in die Bibliometrie. Gesellschaft für Wissenschaftsforschung, Berlin, available online at the URL: http://edoc.hu-berlin.de/oa/books/reMKADKkid1Wk/ PDF/20uf7RZtM6ZJk.pdf

Hummon NP, Doreian P (1989) Connectivity in a citation network: The development of DNA theory. Soc Networks 11(1):39-63 (DOI: 10.1016/0378-8733(89)90017-8)

Krampen G, Becker R, Wahner U, Montada L (2007) On the validity of citation counting in science evaluation: Content analyses of references and citations in psychological publications. Scientometrics 71(2):191-202 (DOI: 10.1007/s11192-007-1659-2)

Kranakis E, Leydesdorff L (1989) Teletraffic conferences: Studying a field of engineering science. Scientometrics 15(5):563-591 (DOI: 10.1007/BF02017071)

Kretschmer H, Kretschmer T (2007) Lotka's distribution and distribution of co-author pairs' frequencies. J Informetr 1(4):308-337 (DOI: 10.1016/j.joi.2007.07.003)

Lambiotte R, Panzarasa P (2009) Communities, knowledge creation, and information diffusion. J Informetr 3(3):180-190 (DOI: 10.1016/j.joi.2009.03.007), also available as arXiv preprint arXiv:0909.2481

Lotka AJ (1911) Die Evolution vom Standpunkte der Physik. Ostwalds Annalen der Naturphilosophie 10:59-74, also available online at the URL: http://digital.slub-dresden.de/id15325443L/65

Lotka AJ (1925) Elements of physical biology. Williams \& Wilkins Company, Baltimore, MD, also available online at the URL: http://www.archive.org/details/elementsofphysic017171mbp. Reprinted as: Lotka AJ (1956) Elements of mathematical biology. Dover Books on the Biological Sciences. Dover, New York, NY

Lotka AJ (1926) The frequency distribution of scientific productivity. J Wash Acad Sci 16(12):317-323 
Lucio-Arias D, Leydesdorff L (2008) Main-path analysis and path-dependent transitions in HistCite ${ }^{\text {TM}}$-based historiograms. J Am Soc Inf Sci Technol 59(12):1948-1962 (DOI:10.1002/asi.v59:12), also available as arXiv preprint arXiv:0911.1454

Lucio-Arias D, Leydesdorff L (2009) The dynamics of exchanges and references among scientific texts, and the autopoiesis of discursive knowledge. J Informetr 3(3):261-271 (DOI:10.1016/j.joi.2009.03.003), also available as arXiv preprint arXiv:0911.1308

MacRoberts MH, MacRoberts BR (1987) Testing the Ortega hypothesis: Facts and artifacts. Scientometrics 12(5):293-295 (DOI: 10.1007/BF02016665)

MacRoberts MH, MacRoberts BR (1989) Problems of citation analysis: A critical review. J Am Soc Inf Sci 40(5):342-349 (DOI: 10.1002/ (SICI) 1097-4571(198909)40:5<342::AID-ASI7>3.0.CO;2-U)

Nicolis G, Prigogine I (1977) Self-organization in nonequilibrium systems: From dissipative structures to order through fluctuations. Wiley, New York, NY

Pastor-Satorras R, Vespignani A (2004) Evolution and structure of the Internet: A statistical physics approach. Cambridge University Press, Cambridge (DOI: 10.1017/CBO9780511610905)

Price DJ de Solla (1965) Networks of scientific papers. Science 149(3683):510-515 (DOI:10.1126/science.149.3683.510). Reprinted in: Price DJ de Solla (1986) Little science, big science ... and beyond. Columbia University Press, New York, NY, pp 103-118

Price DJ de Solla (1976) A general theory of bibliometric and other cumulative advantage processes. J Am Soc Inf Sci 27(5):292-306 (DOI: 10.1002/asi.4630270505), also available online at the URL: http://www.asis.org/Publications/JASIS/Best_Jasist/1976pricejasistarticle.pdf

Pudovkin AI, Garfield E (2002) Algorithmic procedure for finding semantically related journals. J Am Soc Inf Sci Technol 53(13):1113-1119 (DOI: 10.1002/asi.10153), also available online at the URL: http://www.garfield.library.upenn.edu/papers/ pudovkinsemanticallyrelatedjournals2002.html

Pyka A, Scharnhorst A (2009) Introduction. Network perspectives on innovations: Innovative networks - network innovation. In: Pyka A, Scharnhorst A (eds) Innovation networks. New approaches in modelling and analyzing. Springer Complexity: Understanding Complex Systems. Springer, Dordrecht, pp 1-16 (DOI: 10.1007/978-3-540-92267-4_1)

Scharnhorst A (1988) Philosophische, methodologische und erkenntnistheoretische Probleme der Anwendung von Instrumentarien der Physik der Selbstorganisation auf quantitative Aspekte der Wissenschaftsentwicklung. Dr. phil. (PhD) Thesis. Humboldt-Universität zu Berlin, Berlin

Scharnhorst A (2003) Complex networks and the web: Insights from nonlinear physics. J Comput Mediat Commun 8(4), available online at the URL: http://jcmc.indiana.edu/vol8/issue4/ scharnhorst.html

Scharnhorst A, Garfield E (2010) Tracing scientific influence. Dyn Socio-Econ Syst Int J 2(1):133, available online at the URL: http://www.dyses.org.ar/ojs2333/index.php/jdyses/article/ view/11, also available as arXiv preprint arXiv: 1010.3525

Sterman JD (1985) The growth of knowledge: Testing a theory of scientific revolutions with a formal model. Technol Forecast Soc Change 28(2):93-122 (DOI:10.1016/0040-1625(85)90009-5)

Sterman JD (1992) Response to "On the very idea of a system dynamics model of Kuhnian science". Syst Dyn Rev 8(1):35-42 (DOI: 10.1002/sdr.4260080104)

Tabah AN (1999) Literature dynamics: Studies on growth, diffusion, and epidemics. Ann Rev Inf Sci Technol 34:249-86

van Raan AFJ (2006) Statistical properties of bibliometric indicators: Research group indicator distributions and correlations. J Am Soc Inf Sci Technol 57(3):408-430 (DOI: 10.1002/asi.20284)

Van Raan AFJ (2008a) Scaling Rules in the Science System : Influence of Field-Specific Citation Characteristics on the Impact of Research Groups. J Am Soc Inf Sci 59(4):565-576

Van Raan AFJ (2008b) Self-citation as an impact-reinforcing mechanism in the science system. J Am Soc Inf Sci 59(10): 1631-1643

Vinkler P (1996) Relationships between the rate of scientific development and citations. The chance for citedness model. Scientometrics 35(3):375-386 (DOI: 10.1007/BF02016908)

von Neumann J, Morgenstern O (1944) Theory of games and economic behavior. Princeton University Press, Princeton, NJ 
Wagner-Döbler R (1999) William Goffman's "Mathematical approach to the prediction of scientific discovery" and its application to logic, revisited. Scientometrics 46(3):635-645 (DOI: 10.1007/BF02459617)

Weisberg M, Muldoon R (2009) Epistemic landscapes and the division of cognitive labor. Philos Sci 76(2):225-252 (DOI: 10.1086/644786, stable JSTOR URL: http://www.jstor.org/stable/ 10.1086/644786)

Wouters P (1999) The citation culture. Ph.D. Thesis. University of Amsterdam, Amsterdam, available online at the URL: http://garfield.library.upenn.edu/wouters/wouters.pdf

Yablonsky AI (1980) On fundamental regularities of the distribution of scientific productivity. Scientometrics 2(1):3-34 (DOI: 10.1007/BF02016597)

Yin L, Kretschmer H, Hanneman RA, Liu Z (2006) The evolution of a citation network topology: The development of the journal Scientometrics. In: Proceedings of the international workshop on webometrics, informetrics and scientometrics \& seventh COLLNET meeting on 10-12 May, 2006, Nancy (France). SRDI - INIST - CNRS, Nancy, pp 92-113, available online at the URL: http://hdl.handle.net/10760/7576 